\title{
Intravenous apoptotic spleen cell infusion induces a TGF- $\beta$-dependent regulatory T-cell expansion
}

\author{
F Kleinclauss ${ }^{1,2,3,4,5,7}$, S Perruche $e^{1,2,3,4,7}$, E Masson ${ }^{1,2,3,4}$, \\ M de Carvalho Bittencourt ${ }^{1,2,3,4,8}$, S Biichle B $^{1,2,3,4}$, \\ J-P Remy-Martin 1,2,3,4, C Ferrand ${ }^{1,2,3,4}$, M Martin $^{5}$, H Bittard ${ }^{4,5}$, \\ J-M Chalopin ${ }^{1,2,4,6}$, E Seilles ${ }^{1,2,3,4}$, P Tiberghien ${ }^{1,2,3,4}$ and \\ P Saas ${ }^{\star, 1,2,3,4}$ \\ 1 INSERM U645, 1 Bd A Fleming, Besançon F-25020, France \\ 2 Univ Besançon, 1 Bd A Fleming, Besançon F-25020, France \\ ${ }^{3}$ EFS BFC, 1 Bd A Fleming, Besançon F-25020, France \\ ${ }^{4}$ IFR 133, 1 Bd A Fleming, Besançon F-25000, France \\ ${ }^{5} \mathrm{CHU}$ Besançon, Service d'Urologie, St Jacques, Besançon F-25000, France \\ ${ }^{6}$ Service de Néphrologie, St Jacques, Besançon F-25000, France \\ 7 Both these authors contributed equally to this work \\ ${ }^{8}$ Current address: INSERM UMR433, Laboratoire de Virologie-Immunologie, \\ CHRU Fort de France, Martinique F-97261, France \\ * Corresponding author: P Saas, INSERM U645/EA 2284/EFS Bourgogne \\ Franche-Comté, 1 Bd A Fleming, BP1937, Besançon F-25020, France. \\ Tel: + 33-3-81-61-56 15; Fax: + 33-3-81-61-56-17; \\ E-mail: philippe.saas@efs.sante.fr
}

Received 04.4.05; revised 10.5.05; accepted 11.5.05; published online 17.6.05 Edited by M Piacentini

\section{Abstract}

Apoptotic leukocytes are endowed with immunomodulatory properties that can be used to enhance hematopoietic engraftment and prevent graft-versus-host disease (GvHD). This apoptotic cell-induced tolerogenic effect is mediated by host macrophages and not recipient dendritic cells or donor phagocytes present in the bone marrow graft as evidenced by selective cell depletion and trafficking experiments. Furthermore, apoptotic cell infusion is associated with TGF- $\beta$ dependent donor $\mathrm{CD} 4{ }^{+} \mathrm{CD} 25^{+} \mathrm{T}$-cell expansion. Such cells have a regulatory phenotype $\left(C D 62 L^{\text {high }}\right.$ and intracellular CTLA- ${ }^{+}$), express high levels of forkhead-box transcription factor p3 (Foxp3) mRNA and exert ex vivo suppressive activity through a cell-to-cell contact mechanism. In vivo CD25 depletion after apoptotic cell infusion prevents the apoptotic cell-induced beneficial effects on engraftment and GvHD occurrence. This highlights the role of regulatory $T$ cells in the tolerogenic effect of apoptotic cell infusion. This novel association between apoptosis and regulatory T-cell expansion may also contribute to preventing deleterious autoimmune responses during normal turnover.

Cell Death and Differentiation (2006) 13, 41-52.

doi:10.1038/sj.cdd.4401699; published online 17 June 2005

Keywords: transplantation; macrophages; apoptosis; regulatory $\mathrm{T}$ cells

Abbreviations: $\mathrm{Ab}$, antibody; $\mathrm{BM}$, bone marrow; $\mathrm{BMT}$, bone marrow transplantation; CDC, complement-dependent cytotoxicity; DC, dendritic cells; DT, diphtheria toxin; Foxp3, forkhead-box transcription factor p3; GvHD, graft-versus-host disease; HC, hematopoietic cell; mAb, monoclonal antibody; MLR, mixed leukocyte reaction; PerCP, peridinin chlorophyll-a protein; QRTPCR, quantitative real-time PCR; TBI, total body irradiation; Tr1, $T$ regulatory type 1 cells; Treg, regulatory $T$ cells

\section{Introduction}

Immune tolerance is maintained by several mechanisms. ${ }^{1}$ In addition to central tolerance, various peripheral mechanisms, including T-cell anergy or peripheral T-cell deletion, cooperate to prevent unwanted T-cell immune responses directed against self-antigens. ${ }^{1}$ Recently, active suppression by $\mathrm{CD}^{+}{ }^{+} \mathrm{CD}_{25}{ }^{+}$regulatory T cells (Treg) has been extensively explored as a mechanism involved in limiting autoimmunity ${ }^{2,3}$ as well as a way to induce transplantation tolerance. ${ }^{4}$ Thus, $\mathrm{CD}^{+}{ }^{+} \mathrm{CD}_{25}{ }^{+}$Treg cells have been shown to prevent acute graft-versus-host disease (GvHD), ${ }^{5,6}$ a frequent complication of allogeneic hematopoietic cell $(\mathrm{HC})$ transplantation. Expression of CD25 is shared by different CD4 ${ }^{+}$Treg subsets including CD4 ${ }^{+}$CD25 ${ }^{+}$'suppressive' T cells, which act by cell contact-dependent mechanisms, ${ }^{3,7} \mathrm{IL}-10$-producing $\mathrm{T}$ regulatory type 1 (Tr1) cells ${ }^{8}$ and TGF- $\beta$-producing Th3 cells. ${ }^{9}$ Other Treg-associated molecules such as CD62L or CTLA-4 (CD152) are commonly used to identify CD4 ${ }^{+}$Treg cells. $^{4,5}$ Recently, forkhead-box transcription factor p3 (Foxp3, called also scurfin) has emerged as an adequate marker for 'natural' $\mathrm{CD}^{+}{ }^{+} \mathrm{CD}_{25}{ }^{+}$'suppressive' $\mathrm{T}$ cells ${ }^{10-12}$ as well as other peripherally produced $\mathrm{CD} 4{ }^{+} \mathrm{T}$ cells endowed with regulatory properties. ${ }^{13-15}$ However, the phenotypic characterization as well as suppressive mechanism of $\mathrm{CD}^{+}{ }^{+}$Treg cells may differ, depending on the experimental model used. ${ }^{3}$

Apoptosis is a physiological process that liberates intracellular proteins, rendering critical the maintenance of selftolerance. Thus, following normal cellular turnover, billions of apoptotic cells are produced every day without systematically causing autoimmunity. Several peripheral tolerance mechanisms explaining the absence of immune responses against apoptotic cell-derived Ags have been proposed. ${ }^{16-18}$ First, professional phagocytes, such as macrophages ${ }^{19}$ or certain dendritic cells (DC) subsets, ${ }^{20-23}$ quickly capture apoptotic bodies, thereby preventing the release of harmful products from dying cells. ${ }^{24}$ In addition, apoptotic cell death is frequently associated with an immunomodulatory milieu that may neutralize immune cells present in the environment of dying cells. Such milieu consists mainly of anti-inflammatory cytokines like IL-10 or TGF- $\beta$ released by macrophages, which phagocyte apoptotic cells, ${ }^{19,25,26}$ or by circulating monocytes in the absence of phagocytosis. ${ }^{27}$ Furthermore, some cells like T cells may release TGF- $\beta$ or IL-10 in the course of their apoptotic process. ${ }^{28,29}$ Although the release of TGF- $\beta$ or IL-10 during apoptosis has been extensively reported, ${ }^{19,25-29}$ capacities of apoptotic cells to induce a 
$\mathrm{CD}^{+} \mathrm{T}$-cell subset endowed with regulatory properties has not been demonstrated so far.

Allogeneic $\mathrm{HC}$ transplantation is characterized by the presence of immunocompetent cells of both host and donor origin and the subsequent alloreactive conflict. Donor graft rejection is mainly mediated by recipient $\mathrm{T}$ or NK cells that resist the conditioning regimen. In contrast, donor immune cells present in the $\mathrm{HC}$ graft are responsible for inducing GvHD. In some situations, GvHD can be beneficial to the host by limiting leukemia relapse (graft-versus-leukemia effect). Strategies are required to control this alloreactive conflict that follows allogeneic HC transplantation. Physiological mechanisms that maintain immune homeostasis and self-tolerance have been exploited for a long time to induce tolerance to allograft. ${ }^{30}$ In this way, we used intravenous (i.v.) infusion of apoptotic leukocytes to enhance bone marrow (BM) engraftment across major histocompatibility barriers, whatever their origin. ${ }^{31}$ Here, we reported that after infusion, apoptotic spleen cells were engulfed by splenic DCs and macrophages. Depletion of donor phagocytes present in the graft had no effect on apoptotic cell-induced engraftment. Conversely, depletion of host macrophages - but not host DCs - before transplantation prevented apoptotic spleen cell-induced engraftment. Furthermore, apoptotic spleen cell infusion was associated with donor $\mathrm{CD} 4{ }^{+} \mathrm{CD} 25^{+} \mathrm{T}$-cell expansion, which depends on TGF- $\beta$ production. Such cells had a regulatory phenotype (CD62 $\mathrm{L}^{+}$, intracellular $\mathrm{CTLA} 4^{+}$) and expressed high levels of Foxp3 mRNA. Ex vivo, these Treg exerted their suppressive activity through a cell-to-cell contact mechanism independently of IL-10 or TGF- $\beta$. In vivo, these Treg were involved in the protective effect of donor apoptotic spleen cell administration on GvHD occurrence.

\section{Results}

The graft-facilitating effect of apoptotic spleen cell infusion requires host macrophages but not donor phagocytes present in the BM graft

Apoptotic cells are quickly removed by macrophages ${ }^{19,26}$ or some DC subsets. ${ }^{20-23}$ To examine which cell populations would engulf apoptotic cells, recipients were given donor fluorescent-labeled apoptotic spleen cells in addition to the $\mathrm{BM}$ graft. At various times post-bone marrow transplantation (BMT) (30, $45 \mathrm{~min}, 1,2,4$ and $8 \mathrm{~h})$, the spleen, liver and lungs were analyzed to determine where and by which phagocytes apoptotic cells had been engulfed. Analysis of time kinetics revealed that apoptotic spleen cells were quickly removed mainly by splenic phagocytes, since there was no detectable fluorescent signal in the lung or in the liver at any time points after infusion (data not shown). Flow cytometric analysis indicated that splenic DC as well as macrophages were involved in apoptotic cell uptake (Figure 1a). A higher proportion of labeled phagocytes was observed 45 min after infusion, while no signal could be detected in the spleen tested $4 \mathrm{~h}$ after infusion (Figure 1a). Phagocytes involved in apoptotic spleen cell uptake may be resident host splenic phagocytes and/or phagocytes present in donor BM graft that migrate to the spleen after infusion. To evaluate the involvement of donor phagocytes, an enriched Sca- ${ }^{+}$stem cell graft $\left(3 \times 10^{5}\right.$ cells) was used instead of a total BM graft. Despite significant depletion of CD11c ${ }^{+}$cells $(83 \pm 8 \%)$ and $\mathrm{F} 4 / 80^{+}$cells $(95 \pm 9 \%)$ after Sca- $1^{+}$cell enrichment, donor $\mathrm{HC}$ engraftment was conserved (Figure 1b). This suggests that donor phagocytes are not required for the graft-facilitating effect of apoptotic spleen cells.

To deplete resident host phagocytes, liposomes loaded with clodronate ${ }^{32,33}$ were infused before BMT. Pretreatment of mice with clodronate-loaded liposomes reduced significantly both the number of splenic CD11 ${ }^{+}$macrophages and apoptotic cell-induced donor BM engraftment (Figure 1c). As described previously, ${ }^{33}$ we observed that not all splenic DC subsets were depleted by clodronate-loaded liposome infusion due to their anatomic location (Supplementary Figure 1 online). To further explore the role of host DC in the graftfacilitating effect of apoptotic cells, a transgenic mouse model for in vivo DC ablation ${ }^{34}$ was used. Administration of diphtheria toxin (DT) in such recipient transgenic mice allowed splenic DC depletion for $48 \mathrm{~h}$ (Figure 1d and Jung et al. ${ }^{34}$ ). Despite significant depletion of $\mathrm{eGFP}^{+} \mathrm{CD} 11 \mathrm{c}^{+} \mathrm{DC}$ at the time of BMT, the graft-facilitating effect of apoptotic cells was maintained (Figure 1d). This suggests that host DC is not critical for the graft-facilitating effect induced by apoptotic spleen cell infusion. Altogether, these results show that recipient splenic phagocytes and in particular macrophages are involved in the graft-facilitating effect of i.v. apoptotic cell infusion.

\section{I.v. apoptotic spleen cell infusion leads to the TGF- $\beta$-dependent expansion of CD4 ${ }^{+}$CD25 $^{+}$Treg}

We recently reported that i.v. administration of apoptotic spleen cells, simultaneously with BM grafts, favored engraftment via a TGF- $\beta$-dependent mechanism. ${ }^{35}$ As TGF- $\beta$ can be implicated in the generation of Treg subpopulations, ${ }^{9,13-15}$ and as fluorescent apoptotic bodies within splenic phagocytes could be found (Figure 1a), we first analyzed the spleen for the presence of $\mathrm{CD} 4{ }^{+} \mathrm{CD} 25^{+} \mathrm{T}$ cells at weeks 7-9 post-BMT. Analysis of splenic $\mathrm{T}$-cell populations in mice given apoptotic cells revealed a CD4 ${ }^{+} \mathrm{CD} 25^{+}$T-cell increase in engrafted versus nonengrafted recipients $(8.8 \pm 0.6$ versus $3.9 \pm 0.4 \%$, mean \pm S.E.M., 10 mice per group, $P<0.01$, Figure 2 a). All these recipient mice exhibited a similar splenic cellularity (between 70 and $100 \times 10^{6}$ cells). Expansion of CD4 ${ }^{+}$CD25 ${ }^{+}$ $\mathrm{T}$ cells was restricted to engrafted mice and specific to apoptotic cell infusion, since no such increase was observed in recipient mice engrafting after infusion of a higher number of $\mathrm{BM}$ cells $\left(3 \times 10^{6} \mathrm{BM}\right.$ cells, $\left.1.0 \pm 0.2 \%, n=8, P<0.05\right)$ or after an increased conditioning regimen (total body irradiation (TBI) dose: $7 \mathrm{~Gy}, 1.5 \pm 0.2 \%, n=5, P<0.05)$ in the absence of apoptotic cells (Figure 2a). Such $\mathrm{CD} 4{ }^{+} \mathrm{CD}_{2} 5^{+}$T-cell increase - observed 7-9 weeks after apoptotic cell infusion - was not systematically found in the blood nor in other organs tested, including BM, cervical as well as inguinal lymph nodes (data not shown). To determine the role of TGF- $\beta$ in this apoptotic cell-induced increase, $\mathrm{CD} 4{ }^{+} \mathrm{CD} 25^{+} \mathrm{T}$ cells were analyzed at weeks $7-9$ after BMT and TGF- $\beta$ neutralization. Mice treated with anti-TGF- $\beta$ antibody (Ab) did not exhibit any increase in splenic $\mathrm{CD}^{+}{ }^{+} \mathrm{CD} 25^{+} \mathrm{T}$ cells (Figure $2 \mathrm{~b}$ ). In 


\section{a Fluorescent apoptotic cell:}

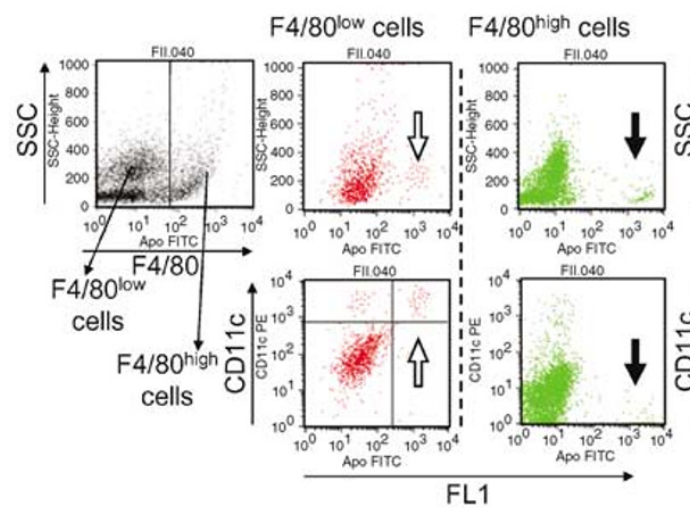

b

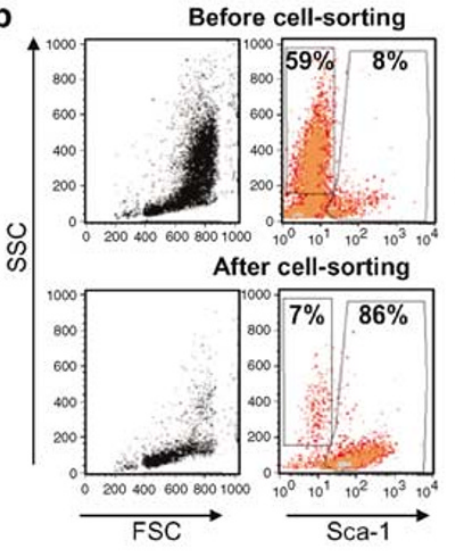

C

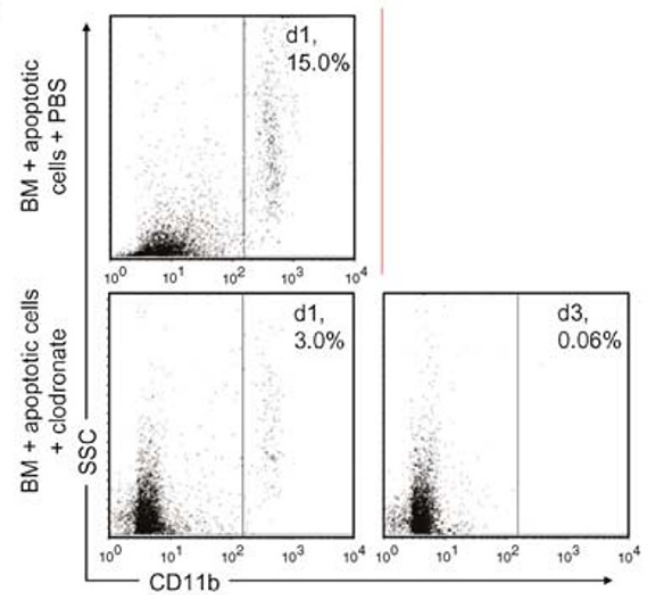

Non-fluorescent apoptotic cell:

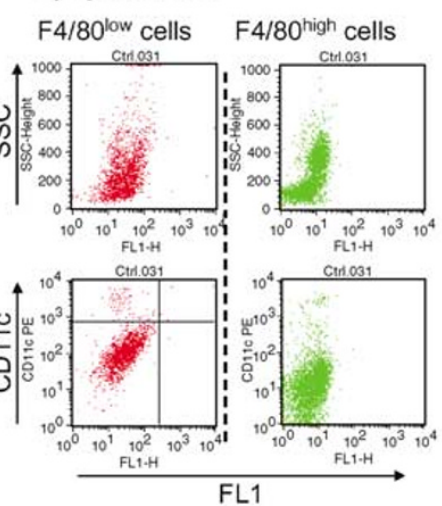

FL1
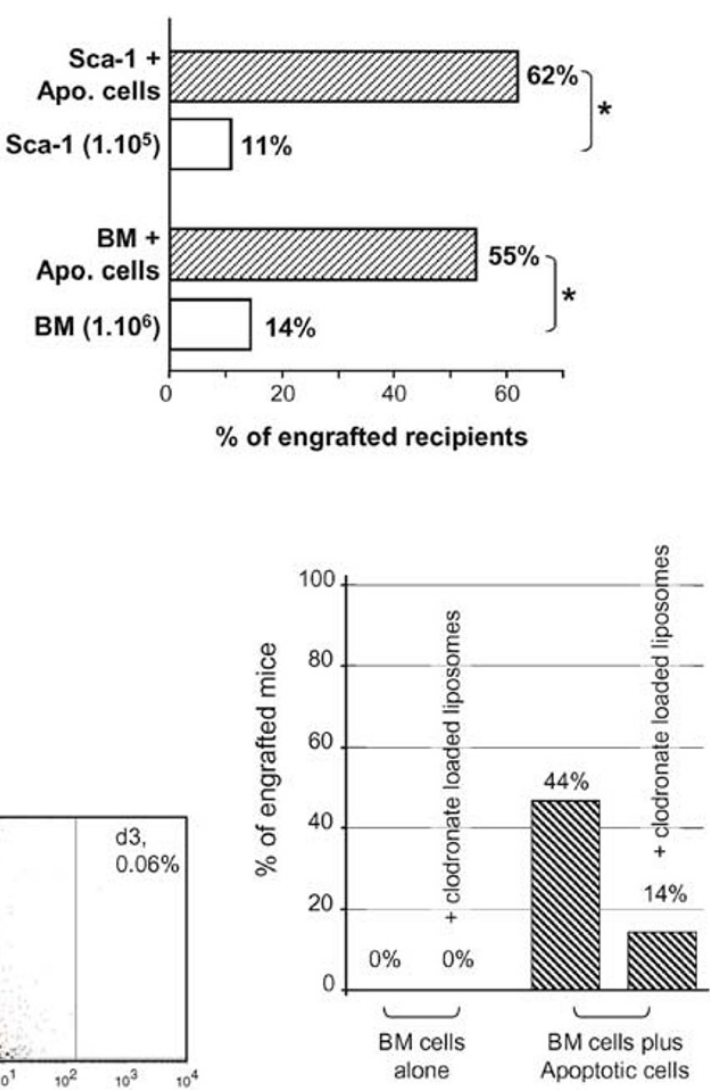

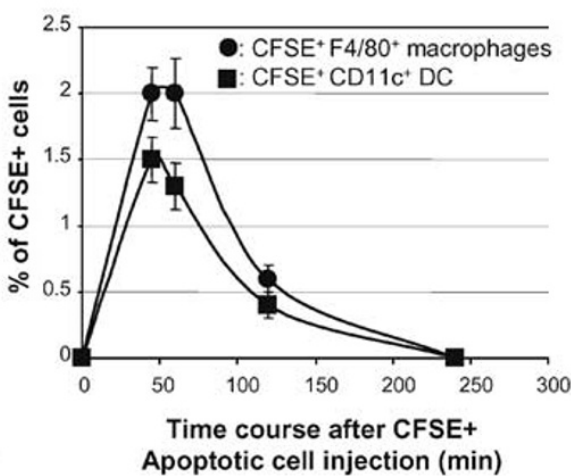

d
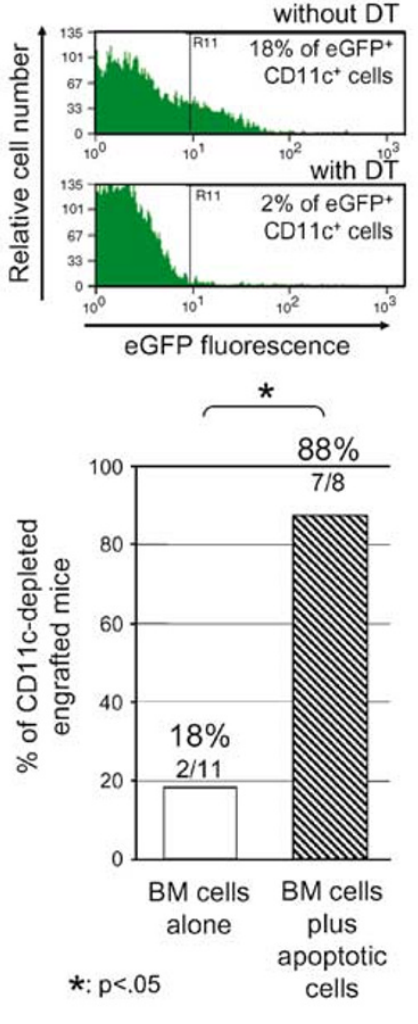

Figure 1 Recipient macrophages are mainly involved in the graft-facilitating effect of apoptotic spleen cell infusion. (a) Green-PKH- or CFSE-labeled apoptotic cells (detectable in the FL1 channel) were used to explore phagocytes involved in the apoptotic cell uptake. Left panel: 45 min after BMT, fluorescent apoptotic cells infused simultaneously with $\mathrm{BM}$ graft were found in splenic $\mathrm{DC}\left(\mathrm{F} 4 / 80^{\text {low }} \mathrm{CD} 11 \mathrm{c}^{+} \mathrm{FL} 1^{+}\right.$; white arrows) as well as in macrophages $\left(\mathrm{F} 4 / 80^{\text {high }} \mathrm{CD} 11 \mathrm{c}^{-} \mathrm{FL} 1^{+}\right.$; black arrows). Results from a representative experiment out of four. Middle panel: nonfluorescent apoptotic cells used as controls. Right panel: kinetics of the appearance of $\mathrm{CFSE}^{+} \mathrm{CD}_{11 \mathrm{c}^{+} \mathrm{DC}(\boldsymbol{\square}) \text { and CFSE }}{ }^{+} \mathrm{F} 4 / 80^{+}$macrophages $(\mathbf{O})$ after infusion of CFSE-labeled apoptotic cells. The percentage of $\mathrm{CFSE}^{+}$cells contained within the indicated splenic cell population is listed on the $y$-axis. $n=3$ mice per time point. Bars represent S.D. (b) Sca-1 cell sorting was used to deplete phagocytes from the BM (left panel: a representative sorting experiment out of four). Right panel: donor engraftment after infusion of total C57BL/6 BM (10 ${ }^{6}$ cells) or Sca-1-enriched graft (Sca-1, $10^{5}$ cells) with (Apo cells, hatched bars) or without (white bars) apoptotic cells. Pooled results from three independent experiments (at least 20 mice/group) expressed in $\%$ of engrafted mice. ${ }^{*} P<0.05$. (c) Clodronate-loaded liposomes were infused before BMT to deplete host splenic phagocyting cells. Left panel: flow cytometric CD11b staining shows the effective depletion of $\mathrm{CD}_{11 \mathrm{~b}}{ }^{+}$macrophages at day 3 after clodronate-liposome infusion. $\mathrm{CD} 11 \mathrm{~b}$ staining in PBS-loaded liposome-treated mice was shown as control. Right panel: donor engraftment after infusion of total BM $\left(10^{6}\right.$ cells) with (hatched bars) or without (white bars) apoptotic cells in mice treated by PBSliposomes or clodronate-liposomes. (d) Recipient $\mathrm{CD} 11 \mathrm{c}^{+} \mathrm{DC}$ were depleted at day -1 before BMT using a single infusion of DT. Top panel: a representative depletion of eGFP ${ }^{+} \mathrm{CD}_{11 \mathrm{c}}{ }^{+}$cells after a $20 \mathrm{~h} \mathrm{DT}$ treatment. Bottom panel: donor engraftment after infusion of total BM ( $10^{6}$ cells) with (hatched bars) or without (open bars) apoptotic cells in DT-treated transgenic mice. Pooled results from two independent experiments expressed in $\%$ of engrafted mice. ${ }^{*} P<0.05$ 


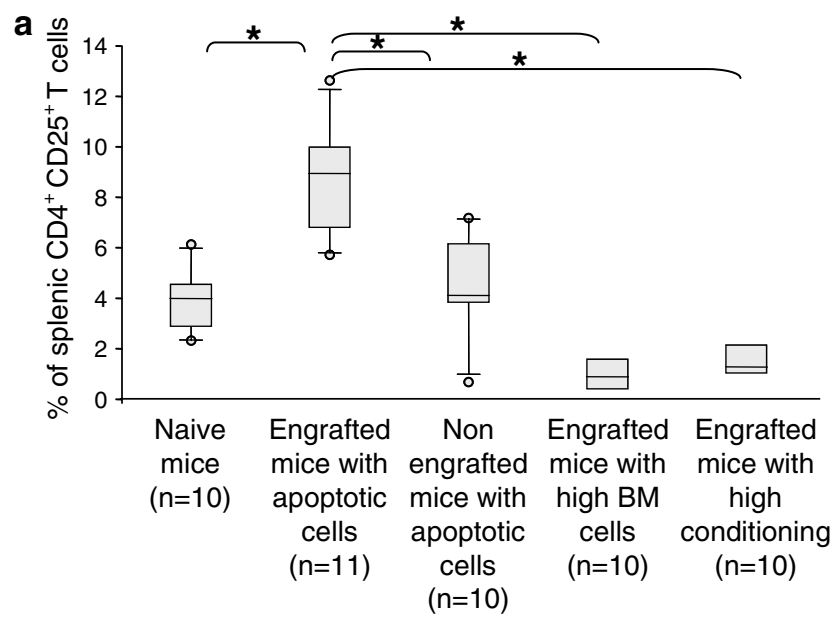

b

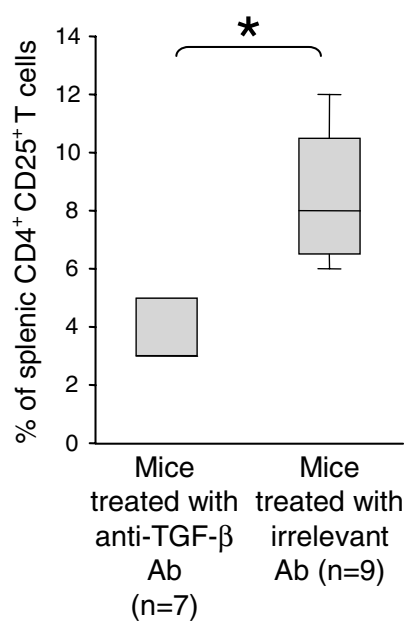

Figure 2 Apoptotic spleen cell infusion simultaneously with a BM graft induces an in vivo TGF- $\beta$-dependent splenic expansion of $\mathrm{CD} 4{ }^{+} \mathrm{CD} 25^{+} \mathrm{T}$ cells. (a) Splenic $\mathrm{CD} 4{ }^{+} \mathrm{CD} 25^{+} \mathrm{T}$ cells increase after apoptotic spleen cell infusion. These cells were evaluated by cytometry in different groups: naive mice, engrafted and nonengrafted mice given apoptotic cells, engrafted mice given only a higher number of BM cells $\left(3 \times 10^{6}\right)$ and engrafted mice given a higher conditioning regimen (7 Gy). Boxes represent mean \pm S.E.M., bars the S.D. and circles the highest and lowest values. ${ }^{*} P<0.01$. (b) TGF- $\beta$ neutralization inhibits apoptotic spleen cell-induced splenic $\mathrm{CD} 4{ }^{+} \mathrm{CD} 25^{+} \mathrm{T}$-cell increase. The percentage of splenic $\mathrm{CD} 4{ }^{+} \mathrm{CD} 25^{+}$T cells was evaluated $7-9$ weeks post-graft in TGF- $\beta$ mAb-treated mice $(n=7)$ versus in irrelevant isotype Ab-treated mice $(n=9)$. Pooled results of two independent experiments. ${ }^{*} P<0.01$

contrast, mice given irrelevant Ab plus apoptotic cells had similar splenic $\mathrm{CD} 4{ }^{+} \mathrm{CD} 25^{+} \mathrm{T}$-cell levels as mice receiving apoptotic cells (Figure 2b). TGF- $\beta$-neutralizing effect could also be observed in peripheral blood $\left(62 \pm 7 \mathrm{CD} 4{ }^{+} \mathrm{CD} 25^{+} \mathrm{T}\right.$ cells $/ \mu$ in anti-TGF- $\beta$ Ab-treated mice versus $288 \pm 46$ cells $/ \mu \mathrm{l}$ in control $A b$-treated mice; $P<0.01)$. Overall, this suggests that TGF- $\beta$ production is involved in apoptotic cell-induced $\mathrm{CD} 4{ }^{+} \mathrm{CD} 25^{+} \mathrm{T}$-cell increase.

Further phenotypic and functional characterization of splenic $\mathrm{CD} 4{ }^{+} \mathrm{CD} 25^{+} \mathrm{T}$ cells detected in mice given apoptotic spleen cells was performed to know whether such cells displayed regulatory functions. The $\mathrm{CD} 4{ }^{+} \mathrm{CD} 25^{+} \mathrm{T}$ cells present in engrafted mice were of donor origin; they presented a Treg-like phenotype $\left(\mathrm{CD}_{45 \mathrm{RB}}{ }^{\text {low }} \mathrm{CD} 62 \mathrm{~L}^{\text {high }}\right.$ intracellular
CTLA-4 ${ }^{\text {high }}$ ) and expressed high levels of Foxp3 mRNA (Figure $3 \mathrm{a}$ and $\mathrm{b}$ ). In contrast, $\mathrm{CD} 4{ }^{+} \mathrm{CD} 25^{+} \mathrm{T}$ cells found in nonengrafted mice exhibited a phenotype rather consistent with an activated T-cell phenotype (intracellular CTLA-4 ${ }^{\text {low }}$ $\mathrm{CD}^{2} \mathrm{~L}^{\mathrm{low}}$ ) and were, as expected, of host origin (Figure $3 \mathrm{a}$ ). Purified $\mathrm{CD} 4{ }^{+} \mathrm{CD}_{25} 5^{+} \mathrm{T}$ cells from nonengrafted mice expressed low levels of Foxp3 mRNA (Figure 3b). Increase of splenic $\mathrm{CD} 4{ }^{+} \mathrm{CD} 25^{+}$T cells $7-9$ weeks after apoptotic cell infusion was confirmed by direct quantification of FoxP3 mRNA in recipient whole spleen. A nine-fold increase of FoxP3 mRNA expression was detected at weeks 7-9 after BMT in mice given apoptotic cells plus BM in comparison to mice given $\mathrm{BM}$ alone (Figure $3 \mathrm{c}$ ). Finally, $\mathrm{CD} 4{ }^{+} \mathrm{CD} 25^{+} \mathrm{T}$ cells were functionally characterized in in vitro assays. CD25 depletion restored allogeneic proliferation of splenic CD4 ${ }^{+} \mathrm{T}$ cells from engrafted mice that had received apoptotic spleen cells, whereas CD25 depletion did not affect the proliferation of splenic CD4 ${ }^{+} \mathrm{T}$ cells from nonengrafted mice (Figure $3 \mathrm{~d}$ ). In addition, suppressive assays with FACS-sorted $\mathrm{CD}^{+}{ }^{+} \mathrm{CD} 25^{+} \mathrm{T}$ cells demonstrated that apoptotic cellinduced $\mathrm{CD} 4{ }^{+} \mathrm{CD} 25^{+} \mathrm{T}$ cells exerted their suppressive activity through cell contact-dependent mechanisms. Their suppressive activity could only be inhibited by adding a transwell but not by IL-10, TGF- $\beta$, or IL-10 and TGF- $\beta$ neutralization (Figure $3 \mathrm{e}$ ). These results show that simultaneous apoptotic spleen cell and BM infusion induced a TGF- $\beta$ dependent splenic expansion of $\mathrm{CD}_{2} \mathrm{~L}^{\text {high }} \mathrm{CD} 4{ }^{+} \mathrm{CD} 25^{+}$ T cells endowed with regulatory properties at weeks 7-9 after BMT.

\section{Host macrophage but not DC depletion is critical for the induction of splenic CD62L ${ }^{+} \mathrm{CD} 4{ }^{+} \mathrm{CD}^{2} 5^{+}$ $T$ cells after apoptotic spleen cell infusion}

We then considered which host cells phagocyting apoptotic cells (macrophages and/or DC) were responsible for splenic CD62 ${ }^{\text {high }}{ }^{2 D} 4{ }^{+} \mathrm{CD} 25^{+}$T-cell induction. Effects of DC depletion at the time of transplantation were analyzed in CD11c/DTR/eGFP transgenic recipient. No significant modification of $\mathrm{CD}_{2} \mathrm{~L}^{\text {high }} \mathrm{C} 4^{+} \mathrm{CD} 25^{+}$T-cell population was observed when $\mathrm{DC}$ were depleted at the time of transplantation in comparison to non-CD11c-depleted transgenic mice, even after apoptotic spleen cell infusion (Figure 4). Clodronate-liposome infusion at the time of BMT and apoptotic cell infusion induced the failure of both BM engraftment and donor $\mathrm{CD} 4{ }^{+} \mathrm{CD} 25^{+}$T-cell expansion (data not shown). It was thus difficult to know whether donor $\mathrm{CD} 4^{+} \mathrm{CD} 25^{+}$ $T$ cells participated to BM engraftment or whether donor $\mathrm{CD} 62 \mathrm{~L}^{+} \mathrm{CD} 4{ }^{+} \mathrm{CD} 25^{+}$T-cell increase was related to BM engraftment. To answer this question, splenic CD62 ${ }^{\text {high }}{ }^{2 D} 4{ }^{+} \mathrm{CD} 25^{+} \mathrm{T}$ cells were analyzed by cytometry at different early time points after BMT and macrophage depletion (using clodronate-loaded liposome). This phenotype $\left(\mathrm{CD} 62 \mathrm{~L}^{+} \mathrm{CD} 4{ }^{+} \mathrm{CD} 25^{+}\right)$was chosen since we showed that cells with such phenotype express high levels of Foxp3 mRNA (Figure 3b) and exert suppressive activity (Figure 3d and $\mathrm{e}$ ). Early after apoptotic spleen cell infusion (days 6 and 8 after BMT), a significant increase of $\mathrm{CD}_{2} \mathrm{~L}^{+} \mathrm{CD} 4{ }^{+} \mathrm{CD} 25^{+} \mathrm{T}$ cells was observed in the spleen (Figure 5a). This increase was not found in irradiated mice (data not shown), in mice 
a
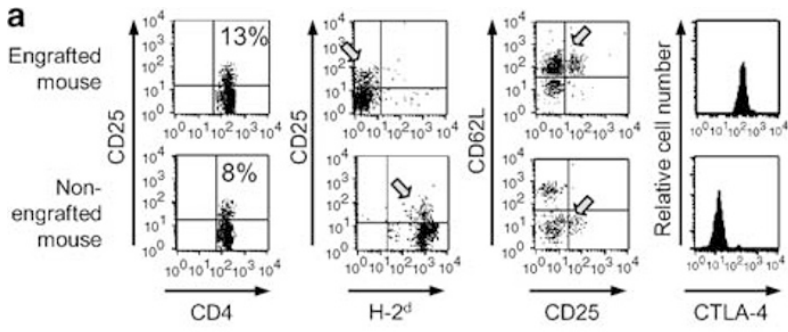

b
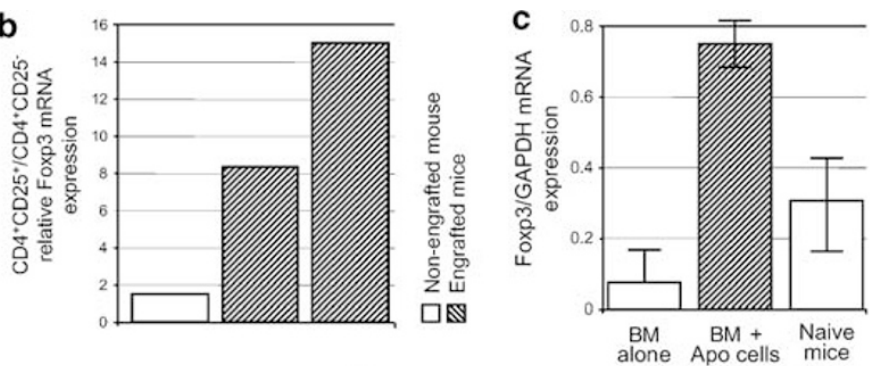

d
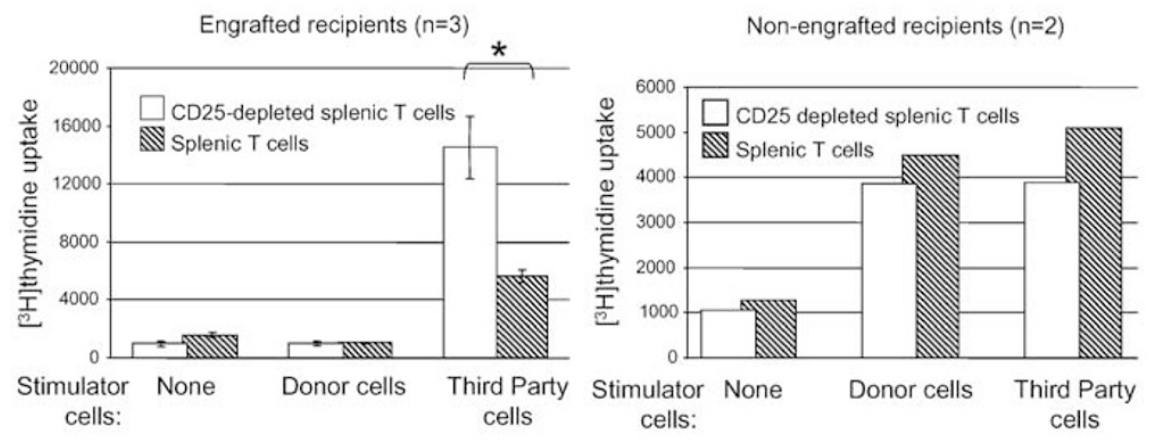

e

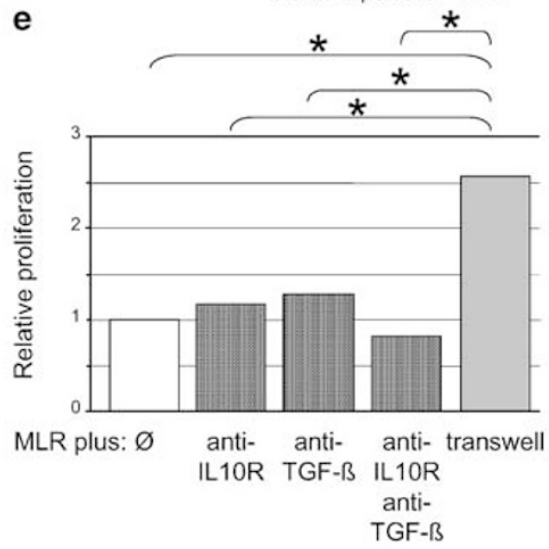

Figure 3 Apoptotic spleen cell infusion simultaneously with a BM graft induces in vivo splenic expansion of CD4 ${ }^{+} \mathrm{CD} 25^{+}$Treg expressing high levels of Foxp3 mRNA and exhibiting in vitro cell-to-cell contact-dependent suppression. (a) Expanded splenic CD4 ${ }^{+} \mathrm{CD} 25^{+} \mathrm{T}$ cells from engrafted and nonengrafted mice were characterized 7-9 weeks post-BMT. CD25, $\mathrm{H}-2^{\mathrm{d}}$ and CD62L expressions were evaluated on the CD4 ${ }^{+} \mathrm{CD}^{+}{ }^{+}$-cell gate $\left(\mathrm{CD} 3^{+}\right.$; $\mathrm{CD}^{+}$; SSC versus FSC), whereas intracellular CTLA-4 expression was evaluated on the $\mathrm{CD} 3^{+} \mathrm{CD} 4{ }^{+} \mathrm{CD} 25^{+} \mathrm{T}$-cell gate. (b) At 7-9 weeks post-BMT, cell-sorted splenic $\mathrm{CD} 4{ }^{+} \mathrm{CD} 25^{+} \mathrm{T}$ cells were analyzed for Foxp3 mRNA expression in engrafted ( $n=2$, hatched bars) and nonengrafted ( $n=1$, open bar) mice that had been given apoptotic cells plus BM cells. Relative Foxp3 mRNA expression was obtained by dividing relative Foxp3 expression in the $\mathrm{CD} 4{ }^{+} \mathrm{CD} 25^{+}$T-cell fraction by that of the CD4 ${ }^{+} \mathrm{CD} 25^{-} \mathrm{T}$-cell fraction. (c) Foxp3 mRNA expression is assessed in whole spleen of either mice given BM alone (left open bars, $n=4$ ), mice given apoptotic cells plus BM (hatched bars, $n=6$ ) 7-9 weeks postBMT. Foxp3 mRNA expression in the spleen of naive BALB/c mice (right open bars, $n=8$ ) was shown as control. Results are expressed as mean \pm S.E.M. of normalized Foxp3 expression (obtained by dividing the relative amount of Foxp3 mRNA for each sample by the relative amount of GAPDH mRNA of the same sample). (d) Splenic CD4 ${ }^{+}$T cells from engrafted (left panel, $n=3$ ) or nonengrafted (right panel, $n=2$ ) BALB/c mice given donor FVB BM and apoptotic cells were cultured with or without allogeneic (FVB donor or C57BL/6 third-party) stimulator cells. T cells were CD25 depleted (open bars) or not (hatched bars). MLR proliferation was assessed by $\left[{ }^{3} \mathrm{H}\right]$ thymidine uptake (c.p.m.). ${ }^{*} P<0.01$. (e) Cell-sorted $\mathrm{CD} 4{ }^{+} \mathrm{CD} 25^{+} \mathrm{T}$ cells were added to an MLR between stimulator-irradiated splenic FVB donor cells and CD25-depleted responder BALB/c recipient CD4 ${ }^{+}$T cells $(n=2)$ with or without $(\varnothing)$ anti-IL10R, anti-TGF- $\beta$ mAb or both. A transwell was also used to separate the MLR from sorted $\mathrm{CD} 4{ }^{+} \mathrm{CD} 25^{+} \mathrm{T}$ cells. Results are expressed as relative proliferation obtained by dividing the $\mathrm{CD} 4{ }^{+} \mathrm{T}$-cell proliferation in response to allogeneic stimulators by the proliferation obtained in similar conditions, but in the presence of blocking Abs or transwell. $\left[{ }^{3} \mathrm{H}\right]$ thymidine uptake $>9000$ c.p.m. ${ }^{*} P<0.05$

receiving $\mathrm{BM}$ alone as well as in mice pretreated with clodronate-loaded liposomes before apoptotic spleen cell and BM infusion (Figure 5a). This shows that macrophage depletion prevents apoptotic spleen cell-induced $\mathrm{CD} 62 \mathrm{~L}^{+} \mathrm{CD} 4{ }^{+} \mathrm{CD} 25^{+}$ $T$-cell increase. In addition, these experiments showed that increase of splenic $\mathrm{CD}_{2} \mathrm{~L}^{+} \mathrm{CD} 4{ }^{+} \mathrm{CD} 25^{+} \mathrm{T}$ cells was detected early in all mice receiving apoptotic cells independently of whether they engrafted or not, and that this increase implicated both donor and recipient $\mathrm{CD}_{22} \mathrm{~L}^{+} \mathrm{CD} 25^{+} \mathrm{CD} 4^{+} \mathrm{T}$ cells (Figure $5 \mathrm{~b}$ ). This suggests that the $\mathrm{CD}_{2} \mathrm{~L}^{+} \mathrm{CD} 4{ }^{+} \mathrm{CD} 25^{+} \mathrm{T}$-cell increase is independent of $\mathrm{BM}$ engraftment and that these cells are induced peripherally after apoptotic cell infusion in the presence of recipient macrophages.

\section{In vivo CD25 depletion after donor apoptotic spleen cell infusion limits the graft-facilitating effect of apoptotic cells}

To determine the role of splenic $\mathrm{CD} 62 \mathrm{~L}^{+} \mathrm{CD} 4{ }^{+} \mathrm{CD} 25^{+} \mathrm{T}$-cell expansion after apoptotic spleen cell infusion, anti-CD25 monoclonal $\mathrm{Ab}(\mathrm{mAb})$ was infused at days 0 and 3 after BMT and engraftment was evaluated at week 7 post-BMT. Despite a significant reduction of peripheral blood $\mathrm{CD} 4{ }^{+} \mathrm{CD} 25^{+}$ T cells 1 week after BMT $(227 \pm 25$ cells $/ \mu$ l in irrelevant $\mathrm{mAb}$ treated mice versus $12 \pm 3$ cells/ $\mu$ in CD25-treated mice), the administration of anti-CD25 mAb did not significantly alter the proportion of engrafted mice $7-9$ weeks post-BMT (50 versus $42 \%$ in mice having received irrelevant mAb, Figure 6). However, CD25 depletion significantly decreased the levels of circulating donor-derived cells in engrafted mice at the time of engraftment analysis $(24.8 \pm 6.4 \%$ donor cells after anti-CD25 $\mathrm{mAb}$ administration versus $72 \pm 15 \%$ after control $\mathrm{mAb}$ treatment, $P<0.05$; Figure 6$)$. This result was not surprising since CD25 is not a specific marker of Treg and is expressed by activated T cells. ${ }^{4}$ Thus, anti-CD25 mAb might deplete both apoptotic cell-induced recipient and donor-derived Treg as well as host activated $T$ cells that limit engraftment. This latter effect could favor donor engraftment explaining why similar proportions of engrafted mice were found after CD25 depletion. Altogether with kinetic studies showing an early increase of $\mathrm{CD} 62 \mathrm{~L}^{+} \mathrm{CD} 4{ }^{+} \mathrm{CD} 25^{+} \mathrm{T}$ cells after apoptotic cell infusion, these in vivo results suggest that 


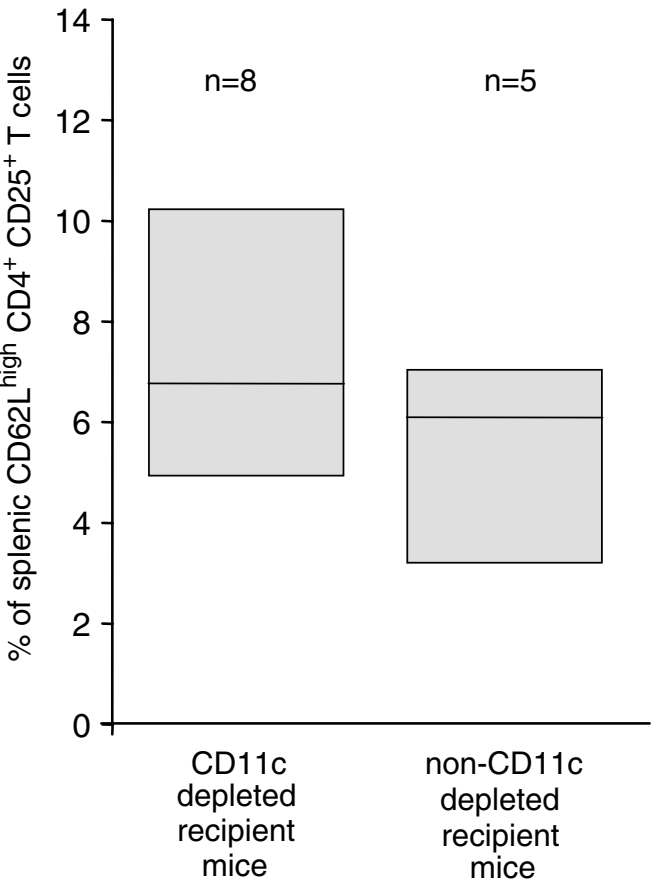

Figure 4 Depletion of $\mathrm{CD} 11 \mathrm{c}{ }^{+} \mathrm{DC}$ h has no effect on $\mathrm{CD} 62 \mathrm{~L}^{\text {high }} \mathrm{CD} 4{ }^{+} \mathrm{CD} 25^{+}$ $\mathrm{T}$-cell increase induced by apoptotic spleen cell infusion. Recipient $\mathrm{CD} 11 \mathrm{c}^{+} \mathrm{DC}$ were depleted at day -1 before BMT using a single infusion of DT. CD11C eGFP/DTR transgenic mice given donor apoptotic cells plus BM were treated (left box, $n=8$ ) or not (right box, $n=5$ ) with DT. CD62L ${ }^{+} \mathrm{CD} 4{ }^{+} \mathrm{CD} 25^{+}$T cells were analyzed by cytometry 7-9 weeks post-BMT. Boxes represent mean \pm S.E.M. and bars the S.D.

CD62 ${ }^{+}{ }^{C D} 4{ }^{+} \mathrm{CD}_{25}{ }^{+} \mathrm{T}$ cells are involved in the graftfacilitating effect observed after apoptotic spleen cell infusion.

\section{Treg expansion is involved in the protective effect of donor apoptotic spleen cell administration on GvHD occurrence}

Apoptotic spleen cell-induced Treg expansion may also be implicated in the prevention of GvHD. We have therefore studied the effects of donor apoptotic spleen cell infusion in an experimental model of GvHD. BALB/c recipient mice were lethally irradiated and the following day received a graft containing donor BM cells plus viable donor splenic T cells (to induce GvHD) with or without apoptotic spleen cells from the $\mathrm{BM}$ donor origin. Apoptotic cell infusion significantly delayed the onset of lethal GvHD in a dose-dependent manner (Figure $7 a$ and $b$ ). We then addressed whether donor $C D 4^{+} \mathrm{CD} 25^{+}$ T-cell expansion was involved in this delayed GvHD lethality observed after donor apoptotic spleen cell infusion. Depleting anti-CD25 mAb was administrated at days 3 and 6 post-BMT. This treatment abolished completely the protective effect of donor apoptotic cell infusion on GvHD (Figure 7c). Overall, these data strongly suggest that donor apoptotic spleen cell infusion induces the expansion of donor-derived $\mathrm{CD}^{+}$ $\mathrm{CD}^{+} 5^{+}$Treg minimizing antirecipient immune responses involved in GvHD lethality.
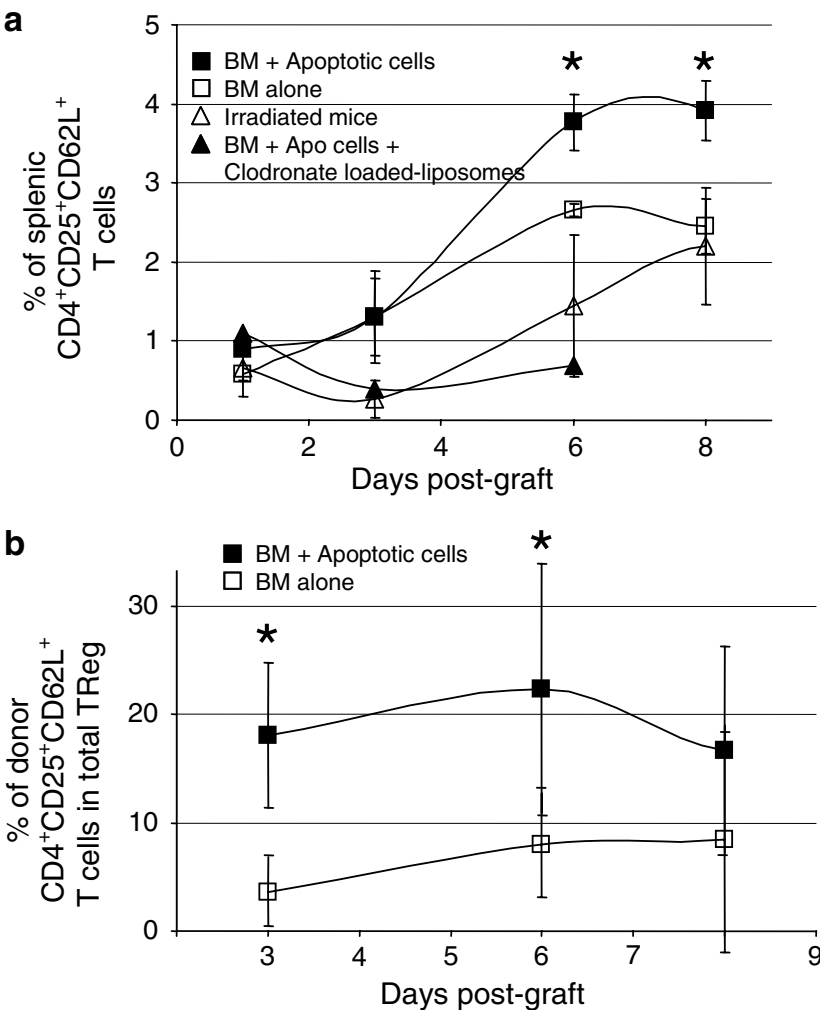

Figure 5 Apoptotic spleen cell infusion simultaneously with a BM graft induces an early increase of $\mathrm{CD} 62 \mathrm{~L}^{+} \mathrm{CD} 4^{+} \mathrm{CD} 25^{+} \mathrm{T}$ cells of both host and donor origin. (a) Host macrophages are involved in the early increase of $\mathrm{CD} 62 \mathrm{~L}^{+} \mathrm{CD} 4{ }^{+} \mathrm{CD} 25^{+} \mathrm{T}$ cells induced by apoptotic spleen cell infusion. Splenic $\mathrm{CD} 62 \mathrm{~L}^{+} \mathrm{CD} 4{ }^{+} \mathrm{CD} 25^{+} \mathrm{T}$ cells were analyzed by cytometry at different time points after the infusion of FVB BM alone $(\square, n=5)$ or FVB BM plus FVB apoptotic cells $(\boldsymbol{\square}, n=5)$. Such cells were also analyzed in BALB/c mice pretreated with clodronate-liposomes and grafted with FVB BM plus FVB apoptotic cells $(\boldsymbol{\Lambda}, n=3)$ and in irradiated BALB/c mice $(\triangle, n=3) .{ }^{\star} P<0.05$. (b) Percentage of donor $\mathrm{CD}_{2} \mathrm{~L}^{+} \mathrm{CD} 4{ }^{+} \mathrm{CD} 25^{+} \mathrm{T}$ cells in the spleen of mice given FVB BM alone $(\square, n=5)$ or BM plus apoptotic spleen cells $(\boldsymbol{\square}, n=5)$ at different early time points after BMT. ${ }^{*} P<0.05$

\section{Discussion}

New therapeutic approaches are required to modulate alloreactivity in $\mathrm{HC}$ transplantation. We recently described an alternative cell-based therapy using i.v. apoptotic leukocyte infusion to favor BM engraftment across MHC barriers. ${ }^{31,35}$ We have previously shown that the apoptotic feature only and not the cell origin is implicated in favoring BM engraftment. ${ }^{31}$ Here, we provide evidence that i.v.-infused apoptotic spleen cells were quickly captured by host splenic macrophages and DC. Donor phagocytes present in the BM graft were not implicated in the graft-facilitating effect of apoptotic spleen cell infusion. In contrast, depletion of host macrophages - but not host DCs - before transplantation prevented apoptotic cell-induced engraftment. Furthermore, apoptotic spleen cell infusion was associated with donor Treg expansion. Ex vivo, these Treg exerted their suppressive activity through a cell-to-cell contact mechanism independently of IL-10 or TGF- $\beta$. Both host macrophages and TGF- $\beta$ production were implicated in this splenic Treg expansion. 


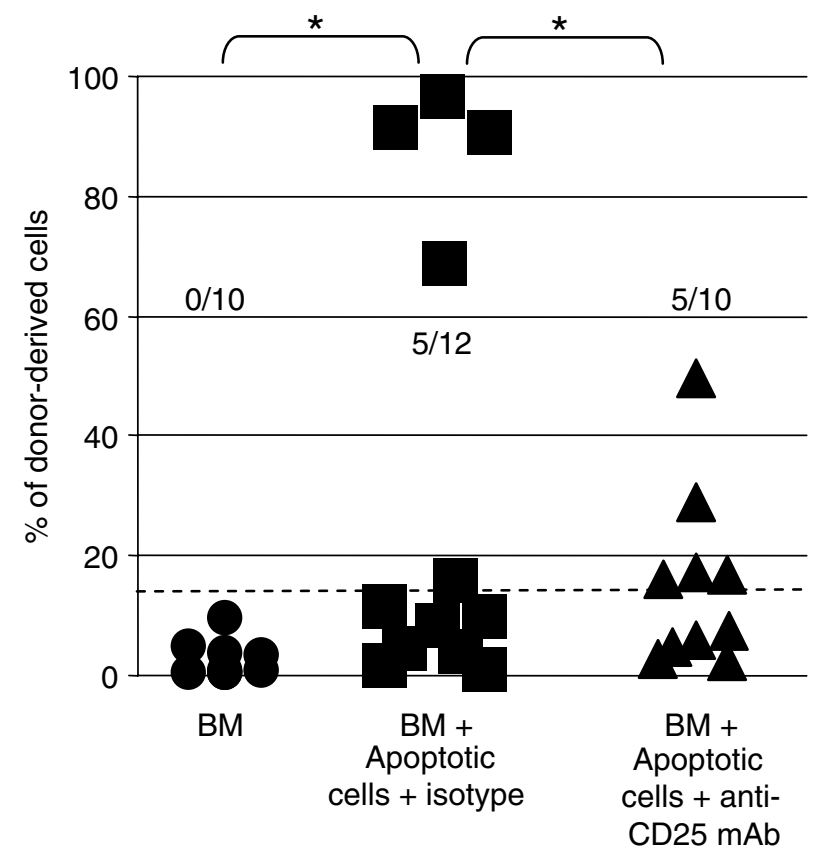

Figure 6 CD25 $5^{+}$cell depletion significantly reduces the number of circulating donor-derived cells after apoptotic spleen cell infusion. The percentage of donorderived cells was evaluated 7-9 week postgraft in the spleen of mice given only $\mathrm{BM}(\boldsymbol{\bullet}, n=10)$, BM and apoptotic cells plus anti-CD25 mAb $(\boldsymbol{\Lambda}, n=10)$ or plus irrelevant $\mathrm{mAb}(\boldsymbol{\square}, n=12)$. The number of engrafted mice in each group was shown. Dotted line indicates $15 \%$ of donor-derived cells corresponding to engraftment. Pooled results of two independent experiments. ${ }^{*} P<0.05$

In vivo CD25 depletion after donor apoptotic spleen cell infusion reduced the rate of donor-derived cells and prevented the protective effect of donor apoptotic cell administration on GvHD occurrence. Altogether, these in vivo results confirm that Treg induced by the simultaneous infusion of donor apoptotic spleen cells and allogeneic grafts are involved in the immunomodulatory effects of such apoptotic cells on alloreactivity.

Apoptotic cells are endowed with immunomodulatory properties. ${ }^{16,17}$ Macrophages involved in apoptotic cell capture have been described to release TGF- $\beta$ both in vitro ${ }^{19}$ and in vivo. ${ }^{26}$ A previous in vitro study reported that TGF- $\beta$ was specifically released by macrophages ingesting apoptotic cells, but not during any other type of phagocytosis. ${ }^{19}$ TGF- $\beta$ production is due mainly to the ligation of phosphatidylserines exposed on apoptotic cells to their receptor expressed on macrophages. ${ }^{36}$ This immunomodulatory milieu created by macrophages participated in the neutralization of unwanted immune responses against apoptotic cell-derived $\mathrm{Ag}^{16,26}$ This may explain why autoimmunity is controlled, although billions of cells die during physiological turnover. Moreover, we have reported the absence of autoimmunity after longterm follow-up of mice that had received a single infusion of apoptotic spleen cells simultaneously with their BM grafts. ${ }^{37}$ TGF- $\beta$ was reported by several groups to induce CD4 ${ }^{+} \mathrm{CD} 25^{+}$T cells endowed with regulatory functions. ${ }^{13-15}$ Several $\mathrm{CD} 4{ }^{+} \mathrm{CD} 25^{+}$T-cell subsets have been described to exert regulatory functions. ${ }^{2-4}$ Sagakuchi's group first demonstrated that $\mathrm{CD}^{+}{ }^{+} \mathrm{T}$ cells expressing $\mathrm{CD} 25$ molecules a
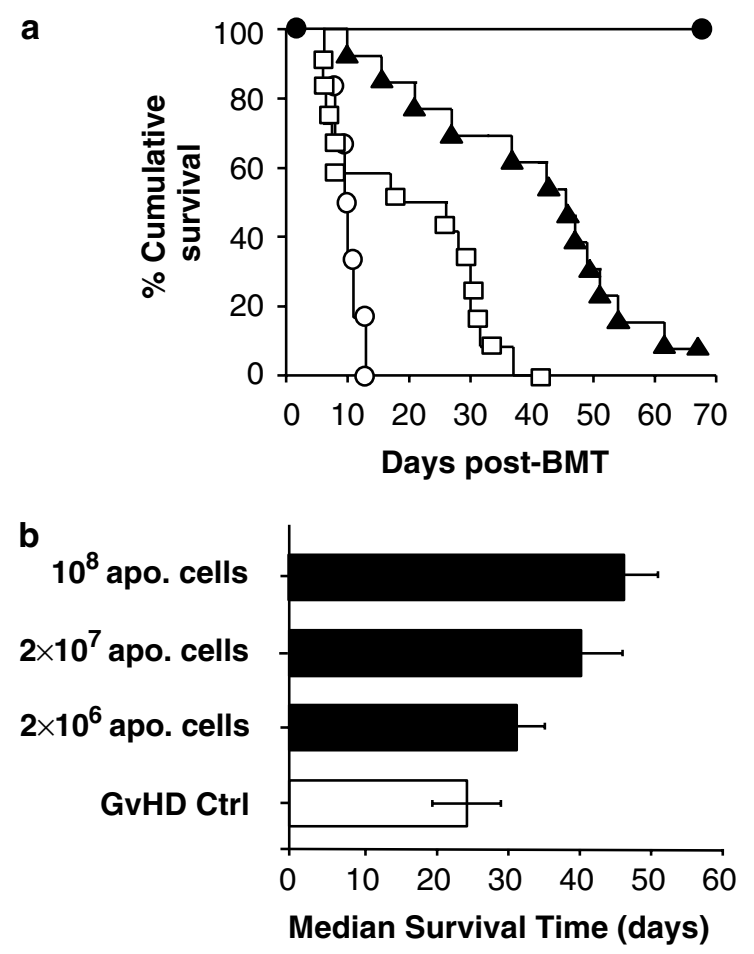

C

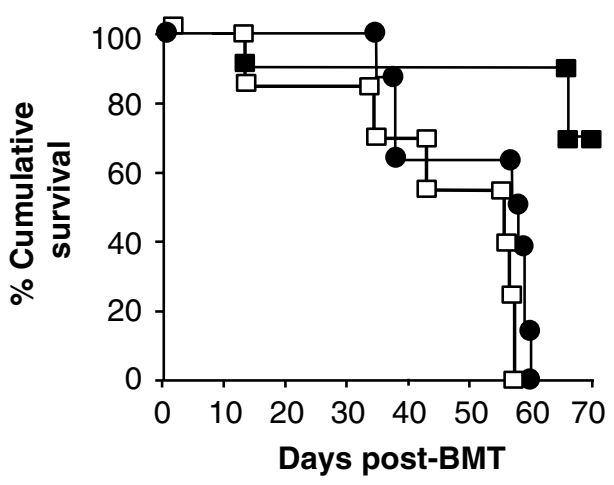

Figure $7 \mathrm{CD}^{2} 5^{+}$cell depletion prevents the protecting effect of donor apoptotic spleen cell administration on GvHD occurrence. (a) Cumulative survival was assessed in the GvHD model in mice receiving donor BM plus splenic T cells and donor apoptotic spleen cells $(\mathbf{\Delta})$ or not (control GvHD group; $\square$ ). Mice receiving BM alone $(\mathbf{O})$ or only lethally irradiated $(O)$ were also used as control. Results of a representative experiment out of four are expressed in \% of cumulative survival. (b) Donor apoptotic spleen cells delay lethal GvHD occurrence in a dose-dependent manner. Median survival time was assessed in mice receiving increasing number of apoptotic cells $\left(2 \times 10^{6}, 2 \times 10^{7}\right.$ or $10^{8}$ apoptotic spleen cells; black bars) or not (GvHD Ctrl group; open bar) in addition to BM and splenic T cells. Pooled results from four independent experiments (10 mice per group, excepted for Ctrl group $n=5$ ) are expressed in median survival time (day) \pm S.D. (c) Delayed CD25 ${ }^{+}$cell depletion abolishes the protective effects of donor apoptotic spleen cell infusion on lethal GvHD occurrence. Cumulative survival was assessed in mice receiving BM plus splenic $T$ cells (GvHD Ctrl group, $\square$ ), with apoptotic cells and treated at days 3 and 6 by anti$\mathrm{CD} 25 \mathrm{mAb}(\boldsymbol{)})$ or irrelevant IgG1 control $(\boldsymbol{\square})$. Results of a representative experiment out of three are expressed in $\%$ of cumulative survival (10 mice per group)

controlled autoimmunity in naive mice. ${ }^{2}$ Here, we strongly suggest a direct link between macrophages, apoptotic spleen cell uptake, TGF- $\beta$ and Treg-like cell expansion. This Treg induction after massive apoptotic primary tissue cell 
death - which was mimicked in our model by i.v. infusion of five millions of apoptotic spleen cells - may constitute an additional mechanism that takes over from TGF- $\beta$ secretion to maintain homeostasis. Since TGF- $\beta$ activation from TGF- $\beta$ latent complex is known to be tightly regulated and lead to a transient effect restricted to neighbor cells, ${ }^{38}$ Treg expansion after massive apoptotic cell death may be responsible for long-term autoimmunity control (either locally or in other sites). Interestingly, induction of Treg cells in the spleen after random blood product transfusion has been reported previously $^{39}$ and nonspecific immunomodulatory effects of preoperative blood product transfusion has been proposed to be related to the presence of apoptotic leukocytes present in stored blood products. ${ }^{16,40,41}$ The immunomodulatory role of apoptotic leukocytes can be also extended to the prevention of alloimmune responses. Sun et al. have recently reported that i.v. infusion of donor apoptotic spleen cells prolongs heart allograft survival. Interestingly, these authors demonstrated that this effect required phagocytosis by host cells. ${ }^{42} \mathrm{We}$ reported that apoptotic spleen cell infusion with an allogeneic graft prevented anti-BM donor alloimmunization even in mice rejecting their grafts. ${ }^{35}$ Treg expansion after apoptotic cell infusion could be beneficial for engraftment as well as to the host (i.e. absence of antidonor immunization or GvHD control).

DC subsets have also been implicated in apoptotic cell uptake $^{17,20-23}$ and subsequent T-cell cross-tolerization. ${ }^{20-22}$ In our model, we found fluorescent apoptotic bodies in splenic DC, suggesting that apoptotic cell-derived $\mathrm{Ag}$ can also be processed by some DC subsets. However, selective DC depletion did not significantly affect either the graft-facilitating effect or splenic Treg expansion after apoptotic spleen cell infusion. Macrophages were thus sufficient to uptake apoptotic cells and possibly released TGF- $\beta$ after phagocytosis. ${ }^{19,26}$ Macrophages were more efficient than immature DC to uptake apoptotic cells ${ }^{43}$ and were found in higher numbers than DC in the spleen. Macrophages may create an immunomodulatory milieu that neutralizes DC Ag-presenting functions. TGF- $\beta$ has been reported to inhibit the ability of $\mathrm{DC}$ to present antigen, stimulate IFN- $\gamma$ production by $\mathrm{T}$ cells and migrate to draining lymph nodes. ${ }^{44}$ Our model made it possible to determine in vivo the respective implications of macrophages and DC after massive apoptotic leukocyte death in an inflammatory situation (i.e. after TBI): macrophages appear as the key players. This sustains the results of Sun et al. ${ }^{42}$

The thymus and the periphery (i.e. where regulation takes place) are both involved in generating Treg. Treg induced by apoptotic cell infusion can be generated from a conversion of peripheral naive $\mathrm{CD} 4^{+} \mathrm{T}$ cells into a regulatory phenotype or by an increased production of natural suppressive $T$ cells after engraftment. In our model, several arguments are in favor of the first hypothesis: preferential expansion in the spleen (where fluorescent apoptotic bodies were found), early induction of both donor and recipient populations (as attested by kinetic studies) and TGF- $\beta$ dependency. Regulatory CD4 ${ }^{+}$ $\mathrm{T}$ cells induced by in vitro TGF- $\beta$ exposure arise from 'conventional' naive $\mathrm{CD} 4{ }^{+} \mathrm{CD} 25^{-}$T-cell precursors. ${ }^{13-15}$ They acquire Foxp3 mRNA expression and exert their suppressive activity mainly through TGF- $\beta .^{13-15}$ In our study, despite TGF- $\beta$ dependency of Treg induction, such cells induced after apoptotic cell infusion expressed high levels of Foxp3 mRNA and exerted ex vivo suppressive activities mainly through a cell contact-dependent activity. However, we cannot exclude that the observed Treg exert their activity through membrane-bound TGF- $\beta$. Membrane TGF neutralization with $\mathrm{mAb}$ is indeed not easy to perform. ${ }^{7}$ Human and murine Treg generated in the periphery from naive $\mathrm{CD}^{2} 5^{-} \mathrm{CD}^{+}{ }^{+} \mathrm{T}$ cells can exert suppression trough a cell-tocell contact-dependent and cytokine-independent mecha nism. ${ }^{45-47}$ Such findings suggest that apoptotic cell-induced Treg that exert cell-to-cell suppression are generated peripherally from $\mathrm{CD}^{+} \mathrm{T}$ cells in the presence of TGF- $\beta$. 'Spontaneous' conversion of $\mathrm{CD}^{+}{ }^{+} \mathrm{CD} 25^{-} \mathrm{T}$ cells into $\mathrm{CD} 2 \mathrm{~L}^{+} \mathrm{Foxp} \mathrm{mRNA}^{+}$Treg after in vivo transfer in syngeneic irradiated recipient has been reported recently. ${ }^{45}$ Thus, in vivo administration of apoptotic cells at the time of infusion of $\mathrm{CD}^{+}{ }^{+} \mathrm{T}$ cells may increase the conversion of such cells into Treg.

Increased BM engraftment linked to Treg induction has only been reported recently. ${ }^{48-50}$ For example, $\mathrm{CD}^{+} \mathrm{TCR}^{-}$facilitating cells, derived from BM, induced Treg genes (including Foxp3) 28 days after transplantation. ${ }^{48}$ This was observed at the time of full donor engraftment, suggesting that these putative CD4 ${ }^{+}$CD25 ${ }^{+}$Treg cells were of donor origin. In this study, upregulation of Treg genes was associated with the absence of GvHD despite donor effector cell administration. ${ }^{48}$ All these data including those on the prevention of $\mathrm{GvHD}^{5,6}$ and our findings highlight the in vivo donor Treg induction/expansion as a promising approach to prevent the deleterious alloreactivity after $\mathrm{HC}$ transplantation.

In conclusion, apoptotic cell infusion enhances BM engraftment by a TGF- $\beta$-dependent mechanism that leads to Treg expansion. For the first time to our knowledge, a link between apoptotic cells and Treg expansion is reported. This could be an additional mechanism to immunomodulatory cytokine production $^{19,25-29}$ or cross-tolerization ${ }^{20-22}$ to prevent deleterious responses against dying cells during normal turnover. We propose to take advantage of this physiological mechanism that maintains self-tolerance to improve $\mathrm{HC}$ transplantation outcomes.

\section{Materials and Methods}

\section{Mice}

Specific pathogen-free 5- to 6-week-old male FVB $\left(\mathrm{H}-2^{\mathrm{q}}\right), \mathrm{C} 57 \mathrm{BL} / 6\left(\mathrm{H}-2^{\mathrm{b}}\right)$ and BALB/C $\left(\mathrm{H}-2^{\mathrm{d}}\right)$ mice (Janvier, Genest-St-Isle, France) were kept in quarantine for at least 1 week before BMT. CD11c/DTR/eGFP transgenic mice from a BALB/c background (kindly provided by $S$ Jung, The Weizmann Institute of Science, Rehovot, Israel) were bred in our animal facility. This transgenic model allows short-term ablation of DC in vivo after administration of DT (100 ng per mouse, Sigma, Saint Quentin Fallavier, France) without affecting macrophages. ${ }^{34}$ Mice were given ad libitum access to food and water. Neomycin sulfate $(1.1 \mathrm{~g} / \mathrm{l}$, Demavic, Longvic, France) was added to their drinking water as of day -1 of BMT to reduce the risk of infection. Experiments were performed according to institutional guidelines. 


\section{Antibodies}

The following $m A b$ were used (all obtained from BD PharMingen, San Diego, CA, USA, except when stated): FITC-labeled anti-H-2q $(\mathrm{KH} 114$, mouse IgG2a), CD8 (53-6.7, rat IgG2a), CD11c (HL3, Armenian hamster IgG), CD19 (1D3, rat IgG2a), CD25 (7D4, rat IgM), CD45RB/B220 (RA36B2, rat IgG2a), Sca-1 (D7, Rat IgG2a), PE-labeled anti-I-A ${ }^{b}(\mathrm{M} 5 /$ 114.15.2, rat $\lg G 2 a$, reacts also with $I-A^{d} I-E^{d} I-E^{k}$ and $\left.I-A^{q}\right), H-2^{d}(S F 1-$ 1.1, mouse lgG2a), CD25 (3C7, rat lgG1 or PC61, rat lgG1), CD62L (MEL14, rat IgG2a), CD117 (2B8, rat IgG2b), CD152 (UC10-4F10-11, Armenian hamster IgG), PE-cyanin 5-labeled F4/80 (A3-1, rat IgG2b, Serotec, Oxford, UK), peridinin chlorophyll-a protein (PerCP)-conjugated anti-CD4 (RM4-5, rat IgG2a), anti-CD3 (145-2C11, hamster lgG1), PerCP cyanin 5.5-conjugated anti-H-2 ${ }^{\mathrm{d}}$ (SF1-1.1), CD11b (M1/70, rat IgG2b) and allophycocyanin-conjugated-anti-CD3 (145-2C11). Azide-free low endotoxin-purified anti-CD25 (3C7, rat IgG2b or PC61, rat IgG1) or control (irrelevant) Abs (BD PharMingen) and anti-pan TGF- $\beta$ (rabbit IgGs) or rabbit IgGs (Sigma) were used in vivo.

\section{Cell preparation}

Donor BM cells from FVB or C57BL/6 mice and splenocytes from BALB/C, C57BL/6 or FVB mice were prepared as described. ${ }^{31,35}$ After isolation procedures, cell viability was always greater than $90 \%$ by Trypan Blue (Sigma) dye exclusion. Sca- $1^{+}$cell-enriched grafts were obtained by immunomagnetic cell sorting (Miltenyi Biotec, Paris, France) from C57BL/ $6 \mathrm{BM}$ cells according to the manufacturer's instructions. Purity assessed by Sca-1 mAb staining was $>80 \%$ and donor BM phagocyte depletion assessed by $\mathrm{CD} 11 \mathrm{c}$ and $\mathrm{F} 4 / 80 \mathrm{mAb}$ staining was $>83 \%$. Splenocyte apoptosis was induced by a $40 \mathrm{~Gy}$ dose of $\gamma$-irradiation $6 \mathrm{~h}$ before infusion to allow apoptotic changes to occur. ${ }^{31}$ Apoptosis was confirmed by FITCconjugated Annexin-V (Beckman Coulter Immunotech, Marseille, France) and flow cytometry as well as Hoechst 33342 (Molecular Probes, Eugene, OR, USA) staining and UV microscopy. The absence of secondary necrosis was documented using Trypan Blue staining just before infusion. At the time of infusion, spleen cells were mainly early-stage apoptotic cells (70-85\% of cells were Annexin- $V$ positive and propidium iodide negative; less than $10 \%$ of cells were propidium iodide positive). ${ }^{31}$ Splenic $\mathrm{CD} 62 \mathrm{~L}^{+} \mathrm{CD} 4{ }^{+} \mathrm{CD}_{25}{ }^{+}$T cells were sorted using an EPICS ALTRA cell sorter (Beckman Coulter Immunotech). The purity achieved was $>95 \%$ and staining these cells did not alter their suppressive function. These purified $\mathrm{CD} 4{ }^{+} \mathrm{CD} 25^{+} \mathrm{T}$ cells were used for in vitro assays and RNA extraction for quantitative real-time PCR (QRT-PCR).

\section{Bone marrow transplantation}

$\mathrm{BALB} / \mathrm{c}$ recipients were exposed to a sublethal single dose (6 Gy at a rate of $2.7 \mathrm{~Gy} / \mathrm{min}$ ) of TBI $16 \mathrm{~h}$ before BMT. After they were given a single i.v. infusion, via a caudal vein, containing a limited number of FVB or C57BL/6 BM cells $\left(10^{6}\right)$ or Sca- $1^{+}$cell-enriched graft $\left(10^{5}\right)$ alone or with apoptotic splenocytes $\left(5 \times 10^{6}\right)$ of various origins (recipient, donor or third-party mice). Both hematopoietic grafts and conditioning regimens were defined to favor autologous reconstitution and not engraftment. ${ }^{31}$ Preliminary experiments indicated that a minimum of $10^{6}$ apoptotic spleen cells were required to favor engraftment. The number of apoptotic spleen cells used exceeds this minimum number of cells by a factor of 5 . In these conditions (i.e. i.v. infusion of $5 \times 10^{6}$ early-stage apoptotic spleen cells simultaneously with BM grafts), no autoimmunity was observed. ${ }^{37}$ To study the effects of donor apoptotic cell infusion on the prevention of acute GvHD, we used a lethal dose of TBI (8 Gy) and a higher number of donor
BM cells $\left(10^{7}\right)$ as well as donor viable splenic T cells $\left(3 \times 10^{6}\right.$ to trigger GvHD) ${ }^{51}$ Increasing numbers of donor apoptotic spleen cells $\left(2 \times 10^{6}\right.$, $2 \times 10^{7}$ or $10^{8}$ ) was infused. No immunosuppressive agents were given at any time.

\section{Ab treatment}

Mice were given $150 \mu \mathrm{g}$ anti-pan TGF- $\beta$ Ab or rabbit IgGs by tail vein injection on day 0 (simultaneously with the graft) and on day $3 .{ }^{35} \mathrm{CD} 25$ cells were depleted by anti-CD25 mAb infusion ( $8.5 \mathrm{mg} / \mathrm{kg}$ or $250 \mu \mathrm{g} /$ mouse) on days 0 and 3 . Treatment efficiency was confirmed by a significant decrease in circulating $\mathrm{CD} 4{ }^{+} \mathrm{CD} 25^{+} \mathrm{T}$ cells $(12 \pm 3$ cells $/ \mu \mathrm{l}, n=3)$ as compared to control mAb-treated mice $(227 \pm 25$ cells $/ \mu l, n=3, P<0.01$, Student's $t$-test).

\section{Host phagocyte depletion}

Host phagocyte depletion was performed using clodronate-loaded liposome administration. Liposome preparation and i.v. infusion were performed as described. ${ }^{32,33}$ Briefly, liposomes consisting of phosphatidyl choline and cholesterol (Sigma) in 6:1 molar ratio were resuspended in PBS and injected via the tail vein (final volume of $0.2 \mathrm{ml}$ containing about $2 \mathrm{mg}$ of clodronate-loaded liposomes). The day after, mice were irradiated and grafted as described above. Host phagocyte depletion was controlled $20 \mathrm{~h}$ after treatment, on two treated mice in each experiment, by immunohistochemistry and cytometry analysis. Spleens were removed, cut $(5-\mu \mathrm{m}$ sections), mounted on microscope slides and air-dried for staining. After endogenous phosphatase quenching by levamisole solution (DakoCytomation, Glostrup, Denmark) and nonspecific site blocking, sections were stained with purified CD11b (M1/70), CD11c (HL3) or control $\mathrm{Ab}$ (BD PharMingen) and revealed by biotinylated-conjugated goat anti-rat or anti-Armenian hamster Ab (Jackson ImmunoResearch, West Grove, PA, USA) followed by a streptavidin/alkaline phosphatase complex (DakoCytomation). Then, a solution of fuchsine substrate chromogen (DakoCytomation) was added. Hematoxylin was used as a counterstain.

\section{BM engraftment}

Detection of engraftment was performed by flow cytometry ${ }^{31,35}$ using $\mathrm{H}-2$ specific mAb on peripheral blood cells and at week 7 or 9 post-BMT on splenic cells. Analysis was performed with a FACSCalibur ${ }^{\mathrm{TM}}$ (BD Biosciences, San Jose, CA, USA) using CellQuest ${ }^{\circledR}$ software (Becton Dickinson) or a CyAn LX ${ }^{\mathrm{TM}}$ (DakoCytomation) using Summit ${ }^{\circledR}$ software (DakoCytomation). Recipients were considered as engrafted when they presented at least $15 \%$ of cells expressing BM donor $\mathrm{H}-2 .{ }^{31}$

\section{Tracking of fluorescent apoptotic cells}

Apoptotic spleen cells $\left(5 \times 10^{6}\right)$ were labeled using either green PKH67 dye (Sigma) or 5,6-carboxyfluorescein diacetate succimidyl ester ${ }^{52}$ (CFSE, Molecular Probes, Eugene, OR, USA) before apoptosis induction according to the manufacturer's instructions. After staining and induction of apoptosis ( $40 \mathrm{~Gy}$ ), fluorescent-labeled apoptotic cells were transplanted as previously described with the BM graft in 6-Gy-irradiated recipients. After 30, $45 \mathrm{~min}, 1,2,4$ and $8 \mathrm{~h}$, mice were $\mathrm{CO}_{2}$ euthanized; spleen, liver and lungs were harvested to perform fluorescent-labeled apoptotic cell tracking. Cells from each organ were stained using PE-conjugated antiCD11c and PE-cyanin 5-conjugated anti-F4/80 mAb and analyzed by cytometry. 


\section{Phenotypic analysis of T-cell subsets}

T-cell subsets from blood, spleen, thymus, BM and LN were analyzed after BMT using specific mAb staining and cytometry. For intracytoplasmic staining, cells were stained with CD3, CD4 and CD25 mAb, fixed in $0.25 \%$ paraformaldehyde (Sigma) in PBS and permeabilized in saponin solution (Sigma) prior to staining with CD152 mAb. Absolute counts of circulating lymphocyte subsets were determined using a single-platform approach based on cytometry and tubes containing a defined number of microbeads (TruCOUNT ${ }^{\mathbb{R}}$, BD Biosciences). ${ }^{53}$

\section{Ex vivo functional analysis of CD4 ${ }^{+} \mathrm{CD}^{2} 5^{+} \mathrm{T}$ cells}

Functional characterization of $\mathrm{CD} 4{ }^{+} \mathrm{CD} 25^{+} \mathrm{T}$ cells was performed using two mixed leukocyte reaction (MLR) assays due to limited material and to avoid pooling spleens from separate experimented mice. In the first assay, we depleted $\mathrm{CD}_{2} 5^{+}$cells among $\mathrm{CD}^{+}{ }^{+} \mathrm{T}$ cells using complementdependent cytotoxicity (CDC) and compared CD25-depleted versus nondepleted splenic CD4 ${ }^{+}$T-cell proliferation after allogeneic stimulation. In the second assay, we added FACS-sorted splenic CD4 ${ }^{+} \mathrm{CD} 25^{+}$ T cells to MLR assays. Spleens from naive FVB (donor origin) or C57BL/6 (third-party origin) mice were 40-Gy irradiated and used as stimulator cells in both assays. In the first assay, splenic CD4 ${ }^{+} \mathrm{T}$ cells from BMT recipients (isolated at week 7 post-BMT) were used as responder cells and cultured for $2 \mathrm{~h}$ in complete medium containing DMEM supplemented with $10 \%$ of heat-inactivated FCS (BioWhittaker, Verviers, Belgium), $5 \times 10^{-5} \mathrm{M} 2-\mathrm{ME}, 2 \mathrm{mM} \mathrm{L-glutamine}, 100 \mathrm{IU} / \mathrm{ml}$ penicillin and $100 \mu \mathrm{g} / \mathrm{ml}$ streptomycin (Sigma). Nonadherent responder cells were washed and incubated for $20 \mathrm{~min}$ with purified either anti-CD25 mAb (3C7) or control $\lg \mathrm{G} 2 \mathrm{a}$ and then with newborn rabbit complement (EFS B/FC, Besançon, France) for $1 \mathrm{~h}$ under agitation at room temperature. After washing, lysis was repeated for $30 \mathrm{~min}$. CD25 depletion was confirmed by cytometry $\left(<0.7 \% \mathrm{CD}^{+}{ }^{+} \mathrm{CD} 25{ }^{+} \mathrm{T}\right.$ cells after CDC). CD25-depleted or control responder cells were stimulated in MLR assays in 96-well round-bottom plates (Sarstedt, Orsay, France) in triplicate for 5 days in complete medium at $37^{\circ} \mathrm{C}$ in a $5 \% \mathrm{CO}_{2}$ incubator. After a 5 -day stimulation, cells were pulsed with $1 \mu \mathrm{Ci}$ of [methyl- ${ }^{3} \mathrm{H}$ ]thymidine (NEN life Science Products, Boston, MA, USA). After approximately $16 \mathrm{~h}$ of additional culture, cells were harvested and radioactivity was counted in a beta scintillation counter (Wallac Betaplate counter, Perkin-Elmer, Norwalk, CT, USA). In the second assay, FACS-sorted CD4 ${ }^{+} \mathrm{CD} 25^{+}$T cells were added to CD25-depleted responder cells from naive BALB/C mice stimulated by allogeneic cells, as described above. To determine the mechanism(s) by which FACS-sorted $\mathrm{CD} 4{ }^{+} \mathrm{CD} 25^{+} \mathrm{T}$ cells exert their suppressive activity, we added $\mathrm{CD} 4{ }^{+} \mathrm{CD} 25^{+} \mathrm{T}$ cells above a cell culture insert $(0.3 \mu \mathrm{m}, \mathrm{BD}$ Biosciences). We also investigated the neutralizing effect of various Abs at a final concentration of $5 \mu \mathrm{g} / \mathrm{ml}$ : anti-pan TGF- $\beta$ polyclonal $A b$, its control $A b$ (Sigma), and anti-IL-10R (1B1.2, kindly provided by K Moore, DNAX Research Institute, Palo Alto, CA, USA, via $H$ Groux, Nice, France), its control mAb (Rat lgG1 mAb, GL113).

\section{Quantitative QRT-PCR for Foxp3 mRNA}

Total RNA was extracted using RNA extraction kit (Qiagen, Valencia, CA, USA) according to the manufacturer's instructions and reverse transcribed using random hexamers and M-MLV reverse transcriptase (Life Technologies, Rockville, MD, USA) to use as a template for QRT-PCR. QRT-PCR reactions were then performed in duplicates using genespecific probes and universal master mix (Qiagen) on an iCycler $i Q$ thermocycler (Bio-Rad Laboratories, Marnes-la-Coquette, France). Pri- mers and dual-labeled fluorescent probes were designed using Primer Express $^{\circledR}$ software (Applied Biosystems, Forster City, CA, USA) to be specific for RNA but not for genomic DNA. Primer pairs and related probes were as follows (sense, antisense and probe, respectively): Foxp3: 5'-CCCACCTACAGGCCCTTCTC-3', 5'-GGCATGGGCATCCACAGT-3' and $5^{\prime}$-FAM-GGACAGACCACACTTCATGCATCAGCTC-TAMRA-3'; and GAPDH (used as endogenous reference): 5'-TTCACCACCATGGA GAAGGC-3' $5^{\prime}$-GGCATGGACTGTGGTCATGA-3' and 5'-FAM-TGCATC CTGCACCACCAACTGCTTAG-TAMRA- ${ }^{\prime}$. For each sequence, a standard curve was generated with a dilution series of a known copy number of the target. The relative amount of each unknown sample was determined automatically with the iCycler iQ ${ }^{\circledR}$ software, using the threshold cycle $\left(C_{t}\right)$. Data were expressed as normalized Foxp3 mRNA expression, which was obtained by dividing the relative amount of Foxp3 mRNA for each sample by the relative amount of GAPDH mRNA of the same sample.

\section{Statistical analysis}

Group comparisons of continuous data were made by Student's $t$-test or Mann-Whitney rank-sum test. Survival data were analyzed using Kaplan-Maier survival analysis. $P$-values $<0.05$ were considered as significant.

\section{Acknowledgements}

We thank Rod Ceredig for critical reading of the manuscript, Hervé Groux and Yann Leverrier for helpful discussion, Stephen Jung for providing us with CD11c/DTR/eGFP transgenic mice, Virginie Mouget for her help with and performance of cell sorting, Chantal Ferniot and Dominique Paris for their expertise in animal care and management, and Jackie Kerveillant for her help in preparing this manuscript. This work was supported by the Association pour la Recherche sur le Cancer (ARC, \#4508), the Comité Départemental de la Ligue contre le Cancer du Jura, the Etablissement Français du Sang (Appel d'offres 2004), the Association Française d'Urologie and ALFEDIAM (to FK). SP received financial support from the ARC.

\section{References}

1. Kamradt T and Mitchison NA (2001) Tolerance and autoimmunity. N. Engl. J. Med. 344: 655-664

2. Sakaguchi S (2000) Regulatory T cells: key controllers of immunologic selftolerance. Cell 101: 455-458

3. Shevach EM (2002) $\mathrm{CD}^{+} \mathrm{CD} 25^{+}$suppressor $\mathrm{T}$ cells: more questions than answers. Nat. Rev. Immunol. 2: 389-400

4. Wood KJ and Sakaguchi S (2003) Regulatory T cells in transplantation tolerance. Nat. Rev. Immunol. 3: 199-210

5. Cohen JL, Trenado A, Vasey D, Klatzmann D and Salomon BL (2002) CD4(+)CD25(+) immunoregulatory T Cells: new therapeutics for graft-versushost disease. J. Exp. Med. 196: 401-406

6. Hoffmann P, Ermann J, Edinger M, Fathman CG and Strober S (2002) Donortype CD4(+)CD25(+) regulatory T cells suppress lethal acute graft-versus-host disease after allogeneic bone marrow transplantation. J. Exp. Med. 196: 389-399

7. Piccirillo CA, Letterio JJ, Thornton AM, McHugh RS, Mamura M, Mizuhara $\mathrm{H}$ and Shevach EM (2002) CD4(+)CD25(+) regulatory T cells can mediate suppressor function in the absence of transforming growth factor beta1 production and responsiveness. J. Exp. Med. 196: 237-246

8. Groux H, O'Garra A, Bigler M, Rouleau M, Antonenko S, de Vries JE and Roncarolo MG (1997) A CD4 ${ }^{+}$T-cell subset inhibits antigen-specific T-cell responses and prevents colitis. Nature 389: 737-742 
9. Weiner HL (2001) Induction and mechanism of action of transforming growth factor-beta-secreting Th3 regulatory cells. Immunol. Rev. 182: 207-214

10. Fontenot JD, Gavin MA and Rudensky AY (2003) Foxp3 programs the development and function of $\mathrm{CD} 4^{+} \mathrm{CD} 25^{+}$regulatory T cells. Nat. Immunol. 4 : 330-336

11. Hori S, Nomura T and Sakaguchi S (2003) Control of regulatory T cell development by the transcription factor Foxp3. Science 299: 1057-1061

12. Khattri R, Cox T, Yasayko SA and Ramsdell $F$ (2003) An essential role for Scurfin in $\mathrm{CD} 4^{+} \mathrm{CD} 25^{+} \mathrm{T}$ regulatory cells. Nat. Immunol. 4: 337-342

13. Chen W, Jin W, Hardegen N, Lei KJ, Li L, Marinos N, McGrady G and Wahl SM (2003) Conversion of peripheral $C D 4^{+} \mathrm{CD} 25$-naive $\mathrm{T}$ cells to $\mathrm{CD} 4^{+} \mathrm{CD} 25^{+}$ regulatory $T$ cells by TGF-beta induction of transcription factor Foxp3. J. Exp. Med. 198: 1875-1886

14. Fantini MC, Becker C, Monteleone G, Pallone F, Galle PR and Neurath MF (2004) Cutting edge: TGF-beta induces a regulatory phenotype in CD4+CD25- $T$ cells through Foxp3 induction and down-regulation of Smad7. J. Immunol. 172: 5149-5153

15. Fu S, Zhang N, Yopp AC, Chen D, Mao M, Chen D, Zhang H, Ding Y and Bromberg JS (2004) TGF-beta induces Foxp3+T-regulatory cells from CD4+CD25 - precursors. Am. J. Transplant. 4: 1614-1627

16. Sun EW and Shi YF (2001) Apoptosis: the quiet death silences the immune system. Pharmacol. Ther. 92: 135-145

17. Steinman RM, Turley S, Mellman I and Inaba K (2000) The induction of tolerance by dendritic cells that have captured apoptotic cells. J. Exp. Med. 191: $411-416$

18. Albert ML (2004) Death-defying immunity: do apoptotic cells influence antigen processing and presentation? Nat. Rev. Immunol. 4: 223-231

19. Fadok VA, Bratton DL, Konowal A, Freed PW, Westcott JY and Henson PM (1998) Macrophages that have ingested apoptotic cells in vitro inhibit proinflammatory cytokine production through autocrine/paracrine mechanisms involving TGF-beta, PGE2, and PAF. J. Clin. Invest. 101 890-898

20. Huang FP, Platt N, Wykes M, Major JR, Powell TJ, Jenkins $C D$ and MacPherson GG (2000) A discrete subpopulation of dendritic cells transports apoptotic intestinal epithelial cells to $T$ cell areas of mesenteric lymph nodes. J. Exp. Med. 191: 435-444

21. Iyoda T, Shimoyama S, Liu K, Omatsu Y, Akiyama Y, Maeda Y, Takahara K, Steinman RM and Inaba K (2002) The CD8 ${ }^{+}$dendritic cell subset selectively endocytoses dying cells in culture and in vivo. J. Exp. Med. 195: 1289-1302

22. Liu K, lyoda T, Saternus M, Kimura Y, Inaba K and Steinman RM (2002) Immune tolerance after delivery of dying cells to dendritic cells in situ. J. Exp. Med. 196: 1091-1097

23. Morelli AE, Larregina AT, Shufesky WJ, Zahorchak AF, Logar AJ, Papworth GD, Wang Z, Watkins SC, Falo Jr LD and Thomson AW (2003) Internalization of circulating apoptotic cells by splenic marginal zone dendritic cells: dependence on complement receptors and effect on cytokine production. Blood 101: 611-620

24. Gallucci $S$ and Matzinger P (2001) Danger signals: SOS to the immune system. Curr. Opin. Immunol. 13: 114-119

25. Voll RE, Herrmann M, Roth EA, Stach C, Kalden JR and Girkontaite I (1997) Immunosuppressive effects of apoptotic cells. Nature 390: 350-351

26. Huynh ML, Fadok VA and Henson PM (2002) Phosphatidylserine-dependent ingestion of apoptotic cells promotes TGF-beta1 secretion and the resolution of inflammation. J. Clin. Invest. 109: 41-50

27. Byrne A and Reen DJ (2002) Lipopolysaccharide induces rapid production of IL-10 by monocytes in the presence of apoptotic neutrophils. J. Immunol. 168 1968-1977

28. Chen W, Frank ME, Jin W and Wahl SM (2001) TGF-beta released by apoptotic $T$ cells contributes to an immunosuppressive milieu. Immunity 14 $715-725$

29. Gao Y, Herndon JM, Zhang H, Griffith TS and Ferguson TA (1998) Antiinflammatory effects of CD95 ligand (FasL)-induced apoptosis. J. Exp. Med. 188: 887-896

30. Adler SH and Turka LA (2002) Immunotherapy as a means to induce transplantation tolerance. Curr. Opin. Immunol. 14: 660-665

31. Bittencourt MC, Perruche S, Contassot E, Fresnay S, Baron MH, Angonin R Aubin F, Herve P, Tiberghien P and Saas P (2001) Intravenous injection of apoptotic leukocytes enhances bone marrow engraftment across major histocompatibility barriers. Blood 98: 224-230
32. Leenen PJ, Radosevic K, Voerman JS, Salomon B, van Rooijen N, Klatzmann D and van Ewijk W (1998) Heterogeneity of mouse spleen dendritic cells: in vivo phagocytic activity, expression of macrophage markers, and subpopulation turnover. J. Immunol. 160: 2166-2173

33. Blazar BR, Lindberg FP, Ingulli E, Panoskaltsis-Mortari A, Oldenborg PA, lizuka K, Yokoyama WM and Taylor PA (2001) CD47 (integrin-associated protein) engagement of dendritic cell and macrophage counter-receptors is required to prevent the clearance of donor lymphohematopoietic cells. J. Exp. Med. 194: $541-549$

34. Jung $S$, Unutmaz D, Wong $P$, Sano G, De los Santos K, Sparwasser T, Wu S, Vuthoori S, Ko K, Zavala F, Pamer EG, Littman DR and Lang RA (2002) In vivo depletion of $\mathrm{CD} 11 \mathrm{c}(+)$ dendritic cells abrogates priming of $\mathrm{CD} 8(+) \mathrm{T}$ cells by exogenous cell-associated antigens. Immunity 17: $211-220$

35. Perruche $S$, Kleinclauss F, Bittencourt MC, Paris D, Tiberghien $P$ and Saas $P$ (2004) Intravenous infusion of apoptotic cells simultaneously with allogeneic hematopoietic grafts alters anti-donor humoral immune responses. Am. J. Transplant. 4: 1361-1365

36. Fadok VA, Bratton DL, Rose DM, Pearson A, Ezekewitz RA and Henson PM (2000) A receptor for phosphatidylserine-specific clearance of apoptotic cells. Nature 405: 85-90

37. Perruche S, Kleinclauss F, Angonin R, Cahn JY, Deconinck E, Reininger L, Boucraut J, Tiberghien P and Saas P (2003) A single intravenous infusion of apoptotic cells, an alternative cell-based therapy approach facilitating hematopoietic cell engraftment, does not induce autoimmunity. J. Hematother. Stem Cell Res. 12: 451-459

38. Letterio JJ and Roberts AB (1998) Regulation of immune responses by TGFbeta. Annu. Rev. Immunol. 16: 137-161

39. Bushell A, Karim M, Kingsley $\mathrm{Cl}$ and Wood KJ (2003) Pretransplant blood transfusion without additional immunotherapy generates $\mathrm{CD} 25^{+} \mathrm{CD} 4^{+}$ regulatory $T$ cells: a potential explanation for the blood-transfusion effect. Transplantation 76: 449-455

40. Dzik WH (2003) Apoptosis, TGF beta and transfusion-related immunosuppression: biologic versus clinical effects. Transfus. Apheresis Sci. 29: $127-129$

41. Snyder EL and Kuter DJ (2000) Apoptosis in transfusion medicine: of death and dying - is that all there is? Transfusion 40: $135-138$

42. Sun E, Gao Y, Chen J, Roberts Al, Wang X, Chen Z and Shi Y (2004) Allograft tolerance induced by donor apoptotic lymphocytes requires phagocytosis in the recipient. Cell Death Differ. 11: 1258-1264

43. Fadok VA, Bratton DL and Henson PM (2001) Phagocyte receptors for apoptotic cells: recognition, uptake, and consequences. J. Clin. Invest. 108: 957-962

44. Kobie JJ, Wu RS, Kurt RA, Lou S, Adelman MK, Whitesell LJ, Ramanathapuram LV, Arteaga CL and Akporiaye ET (2003) Transforming growth factor beta inhibits the antigen-presenting functions and antitumor activity of dendritic cell vaccines. Cancer Res. 63: 1860-1864

45. Walker MR, Kasprowicz DJ, Gersuk VH, Benard A, Van Landeghen M, Buckner $\mathrm{JH}$ and Ziegler SF (2003) Induction of FoxP3 and acquisition of T regulatory activity by stimulated human $\mathrm{CD} 4^{+} \mathrm{CD} 25-\mathrm{T}$ cells. J. Clin. Invest. 112: 1437-1443

46. Apostolou I and von Boehmer $\mathrm{H}$ (2004) In vivo instruction of suppressor commitment in naive T cells. J. Exp. Med. 199: 1401-1408

47. Liang S, Alard P, Zhao Y, Parnell S, Clark SL and Kosiewicz MM (2005) Conversion of $\mathrm{CD} 4^{+} \mathrm{CD} 25$ - cells into $\mathrm{CD} 4^{+} \mathrm{CD} 25^{+}$regulatory T cells in vivo requires B7 costimulation, but not the thymus. J. Exp. Med. 201: $127-137$

48. Colson YL, Christopher K, Glickman J, Taylor KN, Wright R and Perkins DL (2004) Absence of clinical GvHD and the in vivo induction of regulatory T cells following facilitating cell transplantation. Blood 104: 3829-3835

49. Taylor PA, Panoskaltsis-Mortari A, Swedin JM, Lucas PJ, Gress RE, Levine BL, June CH, Serody JS and Blazar BR (2004) L-selectin ${ }^{\text {hi }}$ but not the L-selectin ${ }^{10}$ $\mathrm{CD} 4^{+} \mathrm{CD} 25^{+} \mathrm{T}$ regulatory cells are potent inhibitors of GVHD and BM graft rejection. Blood 104: 3804-3812

50. Hanash $\mathrm{AM}$ and Levy RB (2005) Donor $\mathrm{CD} 4^{+} \mathrm{CD} 25^{+} \mathrm{T}$ cells promote engraftment and tolerance following $\mathrm{MHC}$-mismatched hematopoietic cell transplantation. Blood 105: 1828-1836

51. Contassot E, Ferrand C, Angonin R, Cohen JL, de Carvalho Bittencourt M, Lorchel F, Laithier V, Cahn JY, Klatzmann D, Herve P and Tiberghien P 
(2000) Ganciclovir-sensitive acute graft-versus-host disease in mice receiving herpes simplex virus-thymidine kinase-expressing donor $T$ cells in a bone marrow transplantation setting. Transplantation 69: 503-508

52. Dumitriu IE, Mohr W, Kolowos W, Kern P, Kalden JR and Herrmann M (2001) 5,6-Carboxyfluorescein diacetate succinimidyl ester-labeled apoptotic and necrotic as well as detergent-treated cells can be traced in composite cell samples. Anal. Biochem. 299: 247-252

53. Perruche S, Kleinclauss F, Lienard A, Robinet E, Tiberghien P and Saas $P$ (2004) A single-platform approach using flow cytometry and microbeads to evaluate immune reconstitution in mice after bone marrow transplantation. $\mathrm{J}$. Immunol. Methods 294: 53-66

Supplementary Information accompanies the paper on Cell Death and Differentiation website (http://www.nature.com/cdd) 